\title{
WATER IN PIG NUTRITION: PHYSIOLOGY, ALLOWANCES AND ENVIRONMENTAL IMPLICATIONS
}

\author{
ZDZISLAW MROZ, AGE W. JONGBLOED, NICO P. LENIS \\ AND KAREL VREMAN
}

Institute for Animal Science and Health (ID-DLO), Lelystad, P.O. Box 160, 8200 AD

Lelystad, The Netherlands

\section{CONTENTS}

INTRODUCTION .

PHYSIOLOGICAL REGULATION OF BODY WATER STATUS . . . 138

SPONTANEOUS DRINKING AND INTESTINAL TRANSPORT OF WATER . . 138

EFFECTIVE CIRCULATING VOLUME IN THE VASCULAR SYSTEM . . . 139

CHANGES IN PLASMA OSMOLALITY . . . . . . . . . . . . . 142

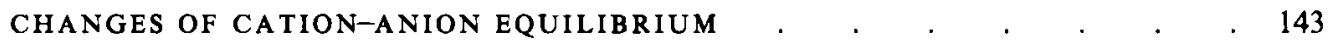

WATER CONSUMPTION: CIRCADIAN RHYTHMICITY . . . . 146

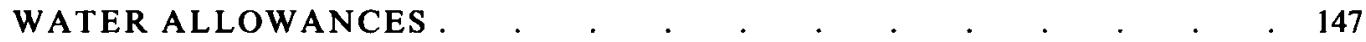

PIGLETS . . . . . . . . . . . . . . . . . . . 148

The sucking piglet. . . . . . . . . . . . . . . . . . . 148

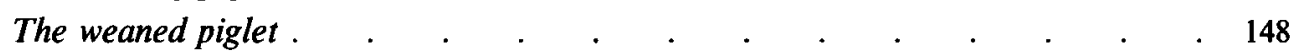

GROWING-FINISHING PIGS . . . . . . . . . . . . . . . . . . . 149

REPRODUCTIVE SOWS . . . . . . . . . . . . . . . . . . . . 151

Non-pregnant and pregnant sows . . . . . . . . . . . . . . . . 151

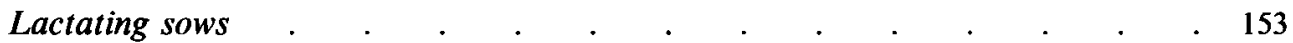

ENVIRONMENTAL IMPLICATIONS . . . . . . . . . . . . . 154

IMPACT OF DIET ON WATER INTAKE AND MANURE PRODUCTION BY PIGS 155

Dietary electrolytes . . . . . . . . . . . . . . . . . . 155

Dietary protein . . . . . . . . . . . . . . . . 157

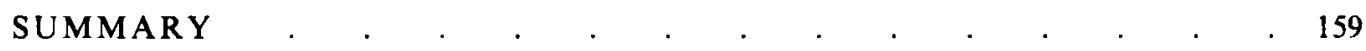

REFERENCES . . . . . . . . . . . . . . . . . 160

\section{INTRODUCTION}

Although water is an essential nutrient, its abundance and low price have not stimulated pig nutritionists to such extensive studies as with the other nutrients. However, pig production on a large scale provides abundant amounts of manure, which is increasingly contributing to environmental pollution and eutrophication of drinking water in some countries (Jongbloed, 1987; Tamminga \& Verstegen, 1992; Barber, 1993). High concentrations of water in the manure (86-98\%) increase costs of storage and disposal (Spoelstra, 1978; Aarnink \& Van Ouwerkerk, 1990; Williams \& Streader, 1990; Cumby et al. 1993). Water in manure originates mainly from excreted urine and this is closely related to water intake. 
The supply of drinking water for pigs in practice is either ad lib. (available over $24 \mathrm{~h}$ or a selected time of day) or restricted (at defined ratios to consumed feed). However, recommended allowances of water for particular categories of pigs differ markedly (Agricultural Research Council, 1981; National Research Council, 1988; Centraal Veevoederbureau, 1993), because of limited information on the underlying physiological mechanisms regulating water consumption and difficulties in establishing the impact of some extrinsic factors, such as ambient temperature, humidity, diet quality and quantity, frequency of water provision, maintenance conditions or stress (Chew, 1965). Besides, the conventional methods of establishing nutrient requirements cannot be applied directly to water since in addition to the requirements for tissue maintenance, body growth, fetus development or lactation, the pig needs water in order to fulfil a number of other physiologically significant functions, namely thermoregulation, mineral homeostasis, excretion of metabolites and/or antinutritional substances, achievement of satiety and behavioural purposes.

Various nutritional factors affect the rate of water consumption and therefore urine production by pigs (Wahlstrom et al. 1970; Hagsten \& Perry, 1976; Friend \& Wolynetz, 1981; Close et al. 1983; Patience et al. 1987; Pfeiffer, 1991).

This review covers most relevant physiological mechanisms regulating body water status with particular emphasis on recommended allowances for drinking water as well as on the relationship between diet composition, water consumption and manure production by various categories of pigs.

\section{PHYSIOLOGICAL REGULATION OF BODY WATER STATUS}

The body water pool accounts for about $60 \%$ of body mass and is distributed among three major compartments: the intracellular space $(36 \%)$, the interstitium $(11.5 \%)$ and the vascular space (4.5\%), remaining in equilibrium across the capillary wall (Rose, 1989). Under normal circumstances, the water content of the body is maintained within relatively narrow limits as variation in the rate of water consumption is matched by appropriate changes in the output of urine. Spontaneous drinking of water and its equilibrium in the body are primarily ascribed to (1) metabolic regulation of the effective circulating volume of fluid in the vascular system, (2) changes in plasma osmolality, and (3) changes in acidbase equilibrium within and between particular compartments. Therefore, these three regulatory factors, as well as hypothetical stimuli inducing spontaneous drinking by pigs, will be discussed in more detail.

\section{SPONTANEOUS DRINKING AND INTESTINAL TRANSPORT OF WATER}

In contrast to humans, rats or dogs, it is not fully understood what stimulates a pig to drink under normal (ad lib.) and stressless conditions. Anderson \& Houpt (1990) indicated from studies on pigs of $15-45 \mathrm{~kg}$ body mass that a rise of about $10 \mathrm{~m}$.osmol kg-1 in plasma and a fall of $6-7 \%$ of blood volume are thresholds for drinking behaviour. The authors admitted, however, that these threshold values for stimulation of drinking by hypertonicity and hypovolaemia are likely to be overestimated, since a range of effective stimuli would be expected depending on the arousal state of the animal. Bigelow \& Houpt (1988) observed that about $75 \%$ of drinking water was taken just before, during, or just after eating. However, Houpt \& Anderson (1990) found no significant differences in osmolality or plasma protein of blood samples taken from pigs during various periods: a resting period (baseline, when not drinking and not eating), a preprandial period (when starting to drink just before eating), a postprandial period (when starting to drink after any eating), 
or a nonprandial period (when starting to drink, but not in association with eating). The authors could observe a significant rise in the haematocrit value from 30.0 to $31.7 \%$ only in the postprandial period. The fall of blood volume in this period was less than $1 \%$, indicating that the preprandial portion of daily water intake may be induced by stimuli other than osmotic or volume changes of body fluids. Houpt et al. (1986) proposed the working hypothesis that, before actual ingestion of feed begins, gastric secretion is initiated by the thought, sight or smell of feed by the hungry pig. The gastric secretagogues (histamine or pentagastrin) would stimulate $\mathrm{H}_{1}$ and $\mathrm{H}_{2}$ histamine sensory receptors present in the gastric mucosa, initiating afferent impulses in the vagus nerves, which in turn would result in activation of the drinking control systems of the hypothalamus, and water drinking would ensue.

Some other hypothetical stimuli for water drinking (increased mucosal blood flow, vascular stretch or distention, the dryness of the mouth) transmitted via chemoreceptors, mechanoreceptors or pressoreceptors to the hypothalamus are cited in the literature (Houpt et al. 1986; Bailey, 1990).

Consumed water is absorbed from the intestine by both active (intracellular) and passive (extracellular) transport (Argenzio, 1984). The first of these is through the cell, and the apical and basolateral membranes must be traversed with energy expenditure. The second pathway is between the cells and through the tight junctions. The active $\mathrm{Na}^{+}$pump at lateral and basal membranes establishes the electrochemical and osmotic gradient for passive bidirectional water flows, from the intestinal lumen into the blood and vice versa. The net movement of fluid into and out of the gut lumen over $24 \mathrm{~h}$ is known as the enterosystemic cycle. The stomach possesses such a tight epithelium that it is almost impermeable even to water. In contrast to the stomach, the duodenum and jejunum have highly permeable epithelia and therefore the osmolality of digesta in those regions equilibrates rapidly with that of the blood. From the jejunum to the colon, the epithelium becomes progressively less permeable, so that in the distal colon a relatively large osmotic gradient and an electric potential difference can be sustained between the lumen and blood. In this way, the colon can adjust the buffering capacity of its contents by absorption or desorption of water and particular electrolytes, although the precise physiological signal for the activation of this operation is as yet unknown (Chang \& Rao, 1994).

\section{EFFECTIVE CIRCULATING VOLUME IN THE VASCULAR SYSTEM}

The effective circulating volume (ECV) refers to that part of the extracellular fluid (ECF) that is in the vascular space and effectively perfusing the tissues (Rose, 1989). Both the ECV and ECF are usually proportional to total body $\mathrm{Na}^{+}$stores, since $\mathrm{Na}^{+}$salts are the primary solutes that act to hold water within the extracellular space. As a result, $\mathrm{Na}^{+}$loading will tend to produce volume expansion (hypervolaemia), whereas $\mathrm{Na}^{+}$loss will lead to volume depletion (hypovolaemia) and induction of thirst. Thirst is defined as a conscious desire to drink and must be differentiated from drinking itself, which may occur for other reasons (Vokes, 1987). The principal stimulus for thirst is an increase in the plasma osmolality. The absolute level of plasma osmolality at which thirst is first perceived is termed the osmotic threshold for thirst.

A primary determinant of renal water excretion is $\mathrm{ADH}$ (antidiuretic hormone, vasopressin, or arginine vasopressin in humans), synthesized in magnocellular neurons of the supraoptic and paraventricular nuclei of the hypothalamus and stored in the posterior part of the pituitary gland, known as the pars nervosa (Vokes, 1987). As for thirst, secretion of ADH is stimulated by a depletion of ECV and hyperosmolality. In general, the plasma $\mathrm{Na}^{+}$concentration is the primary osmotic determinant of $\mathrm{ADH}$ release. According to Rose 
(1989), the osmotic threshold for ADH release in humans is about $280-290 \mathrm{~m} .0 \mathrm{smol} \mathrm{kg}$ and below this level there is little if any circulating ADH. Above the osmotic threshold there is a progressive and relatively linear rise in ADH secretion. This system is so efficient that the plasma osmolality does not usually vary by more than $1-2 \%$, despite wide fluctuations in water intake. ADH augments the water permeability of the luminal membranes of the cortical and medullary collecting tubules of the kidney (by activation of adenylate cyclase; $E C 4.6 .1 .1$ ), allowing osmotic equilibration with the interstitium. It can also promote $\mathrm{NaCl}$ reabsorption in the medullary thick ascending limb, thereby enhancing both urea and $\mathrm{NaCl}$ accumulation in the interstitium. The net effect of these responses is an increase in renal water reabsorption, urine osmolality (in pigs up to $1080 \mathrm{mosmol} \mathrm{I}^{-1}$ ) and a decrease in urine volume (Schmidt-Nielsen et al. 1961; Harper, 1973). Rose (1989) reported that the osmotic threshold for thirst (in humans manifested by a dry mouth) appears to be 2-5 m.osmol kg-1 higher than for ADH release, and drinking leads to a marked, but transient, suppression of thirst and ADH within 10-20 min, before there has been any appreciable reduction in the plasma osmolality.

Regulation of the rate of renal excretion of water and various solutes is influenced also by other hormones, some of which are synthesized within the kidney (renin, calcitriol, prostaglandins and kinins). These hormones can stimulate or inhibit adenylate cyclase, phosphatidylinositol turnover or RNA transcription to permit the maintenance of fluid and electrolyte balance (Randall, 1988).

According to Rose (1989), the body responds to variations in the ECV in two steps: (1) the change is sensed by the volume receptors (the carotid sinuses and aortic arch of the cardiopulmonary circulation, and the juxtaglomerular apparatus of the afferent glomerular arterioles in the kidney, which detect pressure or stretch of the vascular walls), and (2) these receptors then activate a series of effectors (the sympathetic nervous system, the renin-angiotensin-aldosterone system, the glomerular filtration rate, peritubular capillary haemodynamics, atrial natriuretic peptide, pressure natriuresis or plasma $\mathrm{Na}^{+}$concentration), which restore normovolaemia by varying vascular resistance, cardiac output, and renal $\mathrm{Na}^{+}$and water excretion.

If the volume deficit is small (about $10 \%$ of the blood volume), these sympathetic effects return the cardiac output and blood pressure to normal, although the heart rate is likely to be increased. With more severe hypovolaemia (16-25\% of the blood volume), there is increased sympathetic and angiotensin II-mediated vasoconstriction, which results in the shunting of blood away from the mesenteric, renal and musculocutaneous circulations with the relative preservation of cerebral and coronary blood flow (MacFarlane, 1976).

Clinical symptoms of the effective volume depletion in humans are urine $\mathrm{Na}^{+}$ concentration below 10-15 m.equiv. $\mathrm{l}^{-1}$, and when the effective volume is expanded, the urinary $\mathrm{Na}^{+}$concentration can exceed 100 mequiv. $1^{-1}$ (Rose, 1989).

In healthy animals the ECV varies closely with blood volume. Vaissaire (1982) indicated that the normal circulatory blood volume in pigs weighing 10,40 and $100 \mathrm{~kg}$ was 95,73 and $58 \mathrm{ml} \mathrm{kg}^{-1}$ of body mass respectively. The normal circulatory plasma volume is in the range $42.4-54.6 \mathrm{ml} \mathrm{kg}^{-1}$ body mass (Hannon et al. 1990 ). Houpt \& Anderson (1990) estimated the blood volume differences from the measured values of plasma protein concentration (PPC) and plasma cell volume (PCV, haematocrit value) in studies on water consumption by pigs. Although the absolute blood volumes were not determined, the ratio between baseline blood volume $\left(V_{1}\right)$ and the blood volume $\left(V_{2}\right)$ under any of the other drinking conditions could be estimated according to the following equation:

$$
\frac{V_{2}}{V_{1}}=\left(1-\mathrm{PCV}_{1}\right) \frac{\left(\mathrm{PPC}_{1} / \mathrm{PPC}_{2}\right)}{\left(1-\mathrm{PCV}_{2}\right)}
$$


Table 1. Water content in the whole body of pigs in relation to their age and body weight

\begin{tabular}{rccc}
\hline Body weight $(\mathrm{kg})$ & Age (days) & Water content (\%) \\
\hline 1.2 & 1 & 81.5 \\
2.2 & 17 & 80.6 \\
6.9 & 28 & $65 \cdot 7$ \\
$22 \cdot 7$ & 89 & 64.6 \\
36.9 & 116 & 61.8 \\
56.0 & 144 & 56.4 \\
83.9 & 183 & 50.3 \\
103.2 & 208 & 48.9 \\
\hline
\end{tabular}

Vaissaire, 1982.

Table 2. Approximate daily water balance for three categories of pigs

\begin{tabular}{|c|c|c|c|}
\hline Item & $\begin{array}{l}\text { Growing pig } \\
(60 \mathrm{~kg} \mathrm{BW})\end{array}$ & $\begin{array}{c}\text { Pregnant sow } \\
(140 \mathrm{~kg} \mathrm{BW})\end{array}$ & $\begin{array}{c}\text { Lactating sow } \\
\text { (160 kg BW) }\end{array}$ \\
\hline \multicolumn{4}{|l|}{ Water income $\left(\mathrm{l} \mathrm{d}^{-1}\right)$} \\
\hline Drinking water & $1.91-3.33$ & $2 \cdot 63-5.95$ & $8.05-11 \cdot 75$ \\
\hline Feed moisture ${ }^{\mathrm{b}}$ & 0.38 & 0.36 & 0.73 \\
\hline Metabolic water ${ }^{\mathrm{c}}$ & 0.45 & 1.04 & $1 \cdot 16$ \\
\hline \multicolumn{4}{|l|}{ Water output $\left(1 \mathbf{d}^{-1}\right)$} \\
\hline Body water gain & 0.48 & 0.17 & - \\
\hline Urine $^{a}$ & $0.29-1 \cdot 71$ & $0.67-3.09$ & $0.74-4.45$ \\
\hline Faecese & 0.97 & 0.94 & 1.87 \\
\hline Milk & - & & 4.99 \\
\hline Skin' & 0.42 & 0.72 & 0.78 \\
\hline Lungs $^{8}$ & 0.58 & $1 \cdot 40$ & 1.56 \\
\hline Others ${ }^{\mathrm{h}}$ & - & 0.13 & - \\
\hline
\end{tabular}

Gill, 1989.

Requirement to maintain body water balance.

b Compound diet containing $14 \%$ water.

CAssumed to be to $7.43 \mathrm{ml} \mathrm{kg}^{-1}$ BW daily.

d Range $5-30 \mathrm{ml} \mathrm{kg}^{-1} \mathrm{BW}$ daily, at water content of $95 \%$.

e Water content $70 \%$.

'Equal to $13 \cdot 2 \mathrm{ml} \mathrm{m}^{-2} \mathrm{~h}^{-1}$.

Equal to $0.011 \mathrm{~kg}^{-1} \mathrm{BW}$ daily.

${ }^{n}$ Fetus, womb fluids, membranes.

BW, body weight.

The results can be expressed as a percentage: a ratio of 1.05 will indicate a $5 \%$ greater volume at drinking compared with a baseline.

Apart from the blood volume determinations, body water status can be measured in pigs directly (using post slaughter techniques) or indirectly. Estimates from the first method are presented in Table 1. Muscles, backfat and internal fat contain $72 \cdot 7,16 \cdot 4$ and $38.2 \%$ of water respectively (Desmoulin, 1978).

The indirect method of measuring water status in pigs relies on balancing daily water inputs and outputs. In a steady state, total water intake (drinking + feed moisture + metabolic production due to catabolism of fat, carbohydrates and protein) equals water output (daily body gains, obligatory losses in urine, faeces and milk, and transpiration via the skin and expiration via the lungs). An example of daily water balance (factorial estimates) in three categories of pigs kept in a thermoneutral environment is presented in Table 2. 
In summary, the input and output of water are regulated primarily by changes in volume of drinking water and urine which, in turn, are controlled by thirst and the plasma level of $\mathrm{ADH}$ respectively. Both thirst and the secretion of $\mathrm{ADH}$ from the posterior pituitary are controlled by centres located in the hypothalamus that are stimulated primarily by two physiological mechanisms: increases in plasma osmolality and decreases in the ECV of the vascular system. The threshold values for stimulation of drinking behaviour by hypertonicity and hypovolaemia were a rise of about $10 \mathrm{~m} .0 \mathrm{~mol} \mathrm{~kg} \mathrm{~kg}^{-1}$ in plasma and a fall of $6-7 \%$ of blood volume respectively. When pigs have feed and water freely available, there is a possibility that not only the classic hypertonic and hypovolaemic stimuli but also the gastric secretagogues could be involved in stimulation of preprandial water drinking.

\section{CHANGES IN PLASMA OSMOLALITY}

The factors involved in the maintenance of the ECV are very different from those involved in the maintenance of plasma osmolality. The term osmolality refers to the number of osmoles $/ \mathrm{kg}$ water, and is determined by the ratio of solutes (primarily $\mathrm{Na}^{+}$) to water, whereas the extracellular volume is determined by the absolute amounts of $\mathrm{Na}^{+}$and water that are present (Gürtler et al. 1989). Rose (1989) indicated that changes in the plasma osmolality are sensed by osmoreceptors in the hypothalamus (the subfornical organ, the organum vasculosum of the lamina terminalis, and the nucleus medianus). These receptors affect both water intake and water excretion by influencing thirst and the release of ADH respectively. The latter increases the urine osmolality and causes water retention by enhancing the permeability of the collecting tubules to water (Gürtler et al. 1989). It should be underlined that osmoregulation is achieved by alterations in water balance, and $\mathrm{Na}^{+}$is not directly affected unless there are concurrent changes in volume. Regulation of volume, on the other hand, is to maintain tissue perfusion by modifying $\mathrm{Na}^{+}$excretion, and not osmolality.

The osmolality of plasma $\left(P_{\mathrm{osm}}\right)$ is equal to the sum of the osmolalities of the individual solutes in the plasma. It can be measured by a freezing-point osmometer (Houpt \& Anderson, 1990) or estimated from the following equation (Rose, 1989):

$$
P_{\text {osm }} \approx 2 \times \text { plasma }\left[\mathrm{Na}^{+}\right]+[\text {glucose }] / 18+[\text { blood urea } \mathrm{N}] / 2 \cdot 8 .
$$

However, urea is an ineffective osmole, and the effective plasma osmolality is therefore determined by those osmoles that act to hold water within the extracellular space, i.e. $\mathrm{Na}^{+}$ and glucose:

$$
\text { Effective } P_{\text {osm }} \approx 2 \times \text { plasma }\left[\mathrm{Na}^{+}\right]+\text {[glucose] } / 18 .
$$

Since the body fluids are in osmotic equilibrium, the effective $P_{\text {osm }}$ is the effective osmolality of total body water. A partial list of normal values for plasma or serum solutes and some other constituents related to water consumption by pigs is presented in Table 3.

Normal values for $P_{\text {osm }}$ and effective $P_{\text {osm }}$ in growing pigs are in the range 286-335 and 280-330 mosmol kg-1 respectively (Houpt \& Anderson, 1990). Under normal circumstances, the osmotic pressure of plasma varies only slightly despite wide variations in the intake of fluid and of solutes, and is largely attributable to its content of inorganic salts.

Urine formation begins as the blood enters the glomeruli of the kidney. A large volume of blood, equal to the total blood volume, flows through the kidneys in approximately 4-5 min (Rose, 1989). Average tubular reabsorption of water during $24 \mathrm{~h}$ is 1371 in growing pigs of $50 \mathrm{~kg}$ body mass and 11.51 in piglets (Gürtler et al. 1989).

For example, excess intake of water, which would tend to dilute the plasma and thus reduce its osmotic pressure, produces a renal response which results in excretion of a 
Table 3. Normal values of some constituents in blood (B), plasma (P) or serum (S) of pigs

\begin{tabular}{|c|c|c|c|}
\hline Blood constituent & Value & B, P or $\mathrm{S}$ & References \\
\hline Arterial pH & $7.40-7.53$ & B & Hannon et al. 1990 \\
\hline \multirow{4}{*}{$\begin{array}{l}\text { Arterial } p \mathrm{CO}_{2}(\mathrm{mmHg}) \\
\text { arterial } \mathrm{pO}_{2}(\mathrm{mmHg}) \\
\text { Haematocrit }(\%)\end{array}$} & $35-44$ & B & Hannon et al. 1990 \\
\hline & $73-92$ & B & Hannon et al. 1990 \\
\hline & $29 \cdot 0-33.7$ & B & Dubreuil et al. 1993 \\
\hline & $32-50$ & B & Vaissaire, 1982 \\
\hline \multirow[t]{3}{*}{ Haemoglobin $\left(\mathrm{g} \mathrm{l}^{-1}\right)$} & $10-16$ & B & Vaissaire, 1982 \\
\hline & $7 \cdot 5-14 \cdot 4$ & B & Tumbleson \& Schmidt, 1985 \\
\hline & $7 \cdot 3-10 \cdot 2$ & B & Hannon et al. 1990 \\
\hline \multirow[t]{2}{*}{ BUN† $\left(\mathrm{mg} \mathrm{l}^{-1}\right)$} & $80-240$ & $\vec{P}$ & Vaissaire, 1982 \\
\hline & 320 & $\mathbf{P}$ & Gürtler et al. 1989 \\
\hline \multirow[t]{2}{*}{ BUN $\left(\mathrm{mmol} \mathrm{l}^{-1}\right)$} & $4 \cdot 23-4 \cdot 69$ & s & Dubreuil et al. 1993 \\
\hline & $2 \cdot 0-5 \cdot 4$ & $\mathbf{P}$ & Hannon et al. 1990 \\
\hline \multirow[t]{3}{*}{ Glucose $\left(\mathrm{mg} \mathrm{l}^{-1}\right)$} & $800-1400$ & $\mathbf{P}$ & Vaissaire, 1982 \\
\hline & $650-950$ & $\mathbf{P}$ & Hoffmann, 1981 \\
\hline & $710-1440$ & s & Tumbleson \& Schmidt, 1985 \\
\hline \multirow[t]{2}{*}{ Glucose (mmol l-1) } & $4 \cdot 86-5 \cdot 67$ & $\mathbf{s}$ & Dubreuil et al. 1993 \\
\hline & $2 \cdot 6-6 \cdot 5$ & $\mathbf{P}$ & Hannon et al. 1990 \\
\hline Bicarbonate (mequiv. $1^{-1}$ ) & $22-33$ & $\mathbf{P}$ & Hannon et al. 1990 \\
\hline Lactate $\left(\mathrm{mmol} \mathrm{l}^{-1}\right)$ & $0.5-1.5$ & $\mathbf{P}$ & Hannon et al. 1990 \\
\hline Creatinine $\left(\mu \mathrm{mol}^{-1}\right)$ & $62-131$ & $\mathbf{P}$ & Hannon et al. 1990 \\
\hline \multirow[t]{2}{*}{$\mathrm{Na}$ (mequiv. $\mathrm{1}^{-1}$ ) } & $130-157$ & $\mathbf{s}$ & Tumbleson \& Schmidt, 1985 \\
\hline & $135-150$ & $\mathbf{P}$ & Hoffmann, 1981 \\
\hline \multirow[t]{2}{*}{$\mathrm{Na}\left(\mathrm{mmol} \mathrm{l}^{-1}\right)$} & 146 & $\mathbf{P}$ & Gürtler et al. 1989 \\
\hline & $141.0-141.9$ & $\mathbf{S}$ & Dubreuil et al. 1993 \\
\hline \multirow[t]{3}{*}{ K (mequiv. $\mathrm{I}^{-1}$ ) } & $4 \cdot 4-6.7$ & $\mathbf{P}$ & Hoffmann, 1981 \\
\hline & $3 \cdot 9-4 \cdot 1$ & $\mathbf{P}$ & Hannon et al. 1990 \\
\hline & $4 \cdot 2-4 \cdot 8$ & s & Tumbleson \& Schmidt, 1985 \\
\hline \multirow[t]{2}{*}{$\mathbf{K}\left(\mathrm{mmol} \mathrm{l}^{-1}\right)$} & $5 \cdot 11$ & $\mathbf{P}$ & Gürtler et al. 1989 \\
\hline & $4 \cdot 78-4 \cdot 88$ & S & Dubreuil et al. 1993 \\
\hline \multirow[t]{2}{*}{$\mathrm{Cl}$ (mequiv. $\mathrm{I}^{-1}$ ) } & $94-106$ & $\mathbf{P}$ & Hoffmann, 1981 \\
\hline & $96-110$ & $\mathrm{~s}$ & Tumbleson \& Schmidt, 1985 \\
\hline $\mathrm{Cl}\left(\mathrm{mmol} \mathrm{l}^{-1}\right)$ & $104 \cdot 4$ & $\mathbf{P}$ & Gürtler et al. 1989 \\
\hline
\end{tabular}

$\dagger \mathrm{BUN}=$ Blood urea nitrogen

greater volume of urine with an osmolality less than that of plasma. On the other hand, an increase in plasma osmolality due to water deprivation would be corrected by excretion of a concentrated urine with an osmolality higher than of plasma, and water is reabsorbed at such a rate as to maintain isosmotic conditions in plasma.

\section{CHANGES OF CATION-ANION EQUILIBRIUM}

Since there are numerous sources of information about the fundamentals of cation-anion physiology (Harper, 1973; MacFarlane, 1976; Larvor, 1983; Dwyer et al. 1985; Patience et al. 1987; Laski \& Kurtzman, 1989; Patience, 1989a; Rose, 1989; Sabatini \& Kurtzman, 1989), only some relevant aspects will be discussed in this review.

Water turnover is intimately inter-related to cation-anion equilibrium if viewed in terms of the $\mathrm{HCO}_{3}-\mathrm{CO}_{2}$ buffering system (predominant in the ECF):

$$
\mathrm{H}^{+}+\mathrm{HCO}_{3}{ }^{-} \rightleftharpoons \mathrm{H}_{2} \mathrm{CO}_{3} \rightleftharpoons \mathrm{H}_{2} \mathrm{O}+\mathrm{CO}_{2} \text {. }
$$

The kidneys and lungs play a central role in the maintenance of cation anion equilibrium because they can adjust the rate of acid excretion to meet homeostatic needs. The 
Table 4. Normal values of urine volume and its composition in pigs

\begin{tabular}{|c|c|c|c|}
\hline Item & Value & Category of pigs & References \\
\hline \multirow[t]{3}{*}{ Volume } & $\begin{array}{l}2-61 \\
5-30 \mathrm{ml} \mathrm{kg}\end{array}$ & Adult & $\begin{array}{l}\text { Vaissaire (1982) } \\
\text { Vaissaire (1982) }\end{array}$ \\
\hline & 31 & $50 \mathrm{~kg}$ & Gürtler et al. (1989) \\
\hline & 0.51 & Piglet & Gürtler et al. (1989) \\
\hline Flow & $0.01-0.16 \mathrm{ml} \mathrm{min}^{-1} \mathrm{~kg}^{-1}$ & $20-25 \mathrm{~kg}$ & Hannon et al. (1990) \\
\hline GFR & $3-5 \mathrm{ml} \mathrm{min}^{-1} \mathrm{~kg}^{-1}$ & Miniature pigs & Vaissaire (1982) \\
\hline SG $\|$ & $1010-1050$ & - & Vaissaire (1982) \\
\hline $\mathrm{pH}$ & $5 \cdot 4-7 \cdot 0$ & - & Vaissaire (1982) \\
\hline Osmolality & $115-546$ mosmol kg-1 & $20-25 \mathrm{~kg}$ & Hannon et al. (1990) \\
\hline \multirow[t]{3}{*}{$\mathrm{Na}$} & 49-193 mequiv. $1^{-1}$ & - & Vaissaire (1982) \\
\hline & $0.15{\mathrm{~g} 100 \mathrm{~m}^{-1}}^{-1}$ & $50 \mathrm{~kg}$ & Gürtler et al. (1989) \\
\hline & $0.047 \mathrm{~g}^{0} 00 \mathrm{ml}^{-1}$ & Piglet & Gürtler et al. (1989) \\
\hline \multirow[t]{3}{*}{$\mathbf{K}$} & 23-66 mequiv. $1^{-1}$ & - & Vaissaire (1982) \\
\hline & $0.35 \mathrm{~g} \mathrm{l}^{-100 \mathrm{ml}^{-1}}$ & $50 \mathrm{~kg}$ & Gürtler et al. (1989) \\
\hline & $0.20 \mathrm{~g}^{100 \mathrm{ml}^{-1}}$ & Piglet & Gürtler et al. (1989) \\
\hline \multirow[t]{3}{*}{$\mathrm{Cl}$} & $70-197$ mequiv. $1^{-1}$ & - & Vaissaire (1982) \\
\hline & $0.23{\mathrm{~g} 100 \mathrm{ml}^{-1}}^{-1}$ & $50 \mathrm{~kg}$ & Gürtler et al. (1989) \\
\hline & $0.145{\mathrm{~g} 100 \mathrm{ml}^{-1}}^{-1}$ & Piglet & Gürtler et al. (1989) \\
\hline $\mathrm{NH}_{3}$ & $10 \cdot 3-77.0$ mequiv. $1^{-1}$ & -- & Vaissaire (1982) \\
\hline Uric acid & $1-2 \mathrm{mg} \mathrm{kg}^{-1} \mathrm{~d}^{-1}$ & -- & Vaissaire (1982) \\
\hline Urea & $430 \mathrm{mg} \mathrm{kg}^{-1} \mathrm{~d}^{-1}$ & - & Vaissaire (1982) \\
\hline Creatinine & $15-25 \mathrm{mg} \mathrm{kg}^{-1} \mathrm{~d}^{-1}$ & 一 & Vaissaire (1982) \\
\hline
\end{tabular}

$\dagger$ c. $95 \%$ of the volume is water (Brooks \& Carpenter, 1990).

$\ddagger$ Glomerular filtration rate.

II Specific gravity.

homeostatic response to changes in cation-anion loads occurs in three stages: (1) chemical buffering by the extracellular and intracellular buffers, (2) changes in alveolar ventilation to control the $p \mathrm{CO}_{2}$, and (3) alterations in renal $\mathrm{H}^{+}$excretion to regulate the plasma $\mathrm{HCO}_{3}{ }^{-}$ concentration and normalize its $\mathrm{pH}$, since from the law of mass action it is known that:

$$
\left[\mathrm{H}^{+}\right]=24 \times\left(p \mathrm{CO}_{2} /\left[\mathrm{HCO}_{3}^{-}\right]\right) \text {. }
$$

During glomerular filtration, the kidney regulates cation-anion disorders in the vascular system by selective elimination of metabolites (end products of catabolism, such as lactic acid, urea, creatinine, hippuric acid, oxalic acid, ketone bodies, phosphates, sulphates) and the principal electrolytes of the ECF via urine.

A partial list of normal values for urine volume and its constituents in pigs is presented in Table 4.

There is still a paucity of information concerning the influence of various dietary cation and/or anion loads on water consumption and its turnover in the pig. In general, it is known that sodium and potassium are the most important osmotic elements that direct the movement of water from one compartment to another in the body and control the total hydration of the body. Often dietary macromineral balance (mequiv. $\mathrm{kg}^{-1}$ ), referred to as dietary undetermined anion (dUA) and calculated as $(\mathrm{Na}+\mathrm{K}+\mathrm{Ca}+\mathrm{Mg})-(\mathrm{Cl}+\mathbf{P}+\mathrm{S})$, is used to represent in part the acidogenicity or alkalinogenicity of a diet due to the relative deficit or excess, respectively, of metabolizable anions (Patience et al. 1987). Some researchers (Madubuike, 1980; Austic et al. 1983; Miller et al. 1984; Moughan \& Smith, 1984) have considered in studies on pigs or poultry only the monovalent mineral ions, named dietary electrolyte balance $(\mathrm{dEB})$, calculated as $(\mathrm{Na}+\mathrm{K}-\mathrm{Cl})$.

Austic \& Patience (1988) suggested that a more accurate assessment of endogenous acid 
or base production can be obtained in terms of absorbed undetermined anion (aUA), which is calculated from differences between dUA and fUA (faecal undetermined anion). Several experiments and reviews on the relationships between dUA or dEB and acid-base status in the vascular system ( $\mathrm{pH}, p \mathrm{CO}_{2}, p \mathrm{O}_{2}, \mathrm{HCO}_{3}^{-}$, buffer base), gastrointestinal tract ( $\mathrm{pH}$, osmolality, and $\mathrm{HCO}_{3}^{-}$and/or electrolyte concentration) and in urine ( $\mathrm{pH}$, osmolality, titratable acid or base, urine anion gap, urinary $\mathrm{Na}$ and $\mathrm{K}$ excretion) have been reported in the literature (Patience et al. 1986, 1987; Austic \& Patience, 1988; Charney \& Feldman, 1989; Emmett \& Seldin, 1989). Increasing the dEB from -50 to 400 mequiv. $\mathrm{kg}^{-1}$ diet resulted in a linear increase $(P<0.05)$ in apparent ileal and total tract digestibility of proximate nutrients and amino acids in growing pigs (Haydon \& West, 1990), suggesting the importance of $\mathrm{dEB}$ in diet formulation.

Metabolic consequences of dietary alkali or acid loads may also be estimated in terms of renal net acid excretion (NAE). In earlier studies of Scott (1971) on growing pigs the NAE was calculated as $\mathrm{H}^{+}{ }_{\mathrm{NH} 4}+\mathrm{H}^{+}{ }_{\text {titr. acid }}-\mathrm{HCO}_{3}{ }^{-}-\mathrm{OH}^{-}{ }_{\text {titr, base }}$, although more recently, Remer \& Manz (1993) proposed two terms, NAE direct $^{=}$titratable acid (TA) + ammonium $\left(\mathrm{NH}_{4}\right)$ - bicarbonate $\left(\mathrm{HCO}_{3}{ }^{-}\right)$, and $\mathrm{NAE}_{\text {indirect }}=\left(\mathrm{Cl}+\mathrm{PO}_{4}+\mathrm{SO}_{4}+\right.$ organic acids $)-(\mathrm{Na}+$ $\mathrm{K}+\mathrm{Ca}+\mathrm{Mg}$ ). However, according to Dwyer et al. (1985), no reliable method of prediction or quantification of the NAE produced by diets is available so far. This statement is ascribed primarily to the limited information on sulphur and chloride contents in feed ingredients and shortcomings in estimations of digestion/intermediary metabolism of individual mineral elements and production of organic acids (Chan, 1974). Nonetheless, from the recent studies of Remer \& Manz (1993) in human beings it can be concluded that an acceptable estimation of urinary mineral and NAE can be attained when the average bioavailability of protein and individual minerals from the whole diet is taken into account.

Apart from the criteria for estimating physiological responses to acid and base loads, it is worth indicating that ultimate meat quality (muscle $\mathrm{pH}$, colour, water holding capacity, glycolytic enzymes and intermediates), which is of great importance for consumers, may be changed by dietary acid-base balance (Ahn et al. 1992) or water supply (Holme \& Robinson, 1965; Cunningham \& Friend, 1966; Kornegay \& Vander Noot, 1968; Jones et al. 1985).

In conclusion, the interrelationships between dietary acid or base loads and water intake, as well as water-electrolyte metabolic turnovers and urinary output, should become more than peripheral subjects in the context of slurry production and meat quality of pigs. Moreover, since altering diet composition can either intentionally or inadvertently change the acid-base status, appetite, nutrient metabolism, growth and meat quality, it seems reasonable to estimate the dUA, aUA, dEB and/or NAE (particularly proposed by Remer \& Manz, 1993) in formulating practical as well as experimental diets for pigs. Implementation of these criteria needs more scrutiny, however, with regard to dietary anionic/cationic composition and estimates of their bioavailability/digestibility. In response to dietary loads of anions and/or cations, not only a change of acid-base status $\left(\mathrm{pH}, \mathrm{HCO}_{3}^{-}, p \mathrm{CO}_{2}\right.$, base excess), but also differences in concentrations of urea, total proteins, glucose, $\mathrm{Na}, \mathrm{Cl}, \mathrm{K}$, hormones (e.g. vasopressin, $\mathrm{ACTH}$ ), and enzymic activity (e.g. lactic dehydrogenase) in the blood have been reported (Scott \& McIntosh, 1975; Honeyfield \& Froseth, 1985; Parrott \& Misson, 1989; Bailey, 1990; Cai \& Zimmerman, 1992).

In addition, specific water quality (hardness, total dissolved solids, $\mathrm{pH}$, alkalinity, iron, chloride, sodium, potassium, calcium, magnesium, sulphates, manganese, nitrates and nitrites) should be considered in nutritional studies within the context of feed composition, since certain features of water can impair appetite and pig performance (Patience, $1989 b$; Brooks \& Carpenter, 1990; Fraser et al. 1990). 


\section{WATER CONSUMPTION: CIRCADIAN RHYTHMICITY}

The behaviour and most metabolic functions of pigs follow a periodicity close to $24 \mathrm{~h}$ (circadian rhythmicity), despite environmental inputs such as constant light, temperature or noise. This rhythmicity originates from inside the body (endogenous) and is attributed to a biological clock controlled by the suprachiasmatic nucleus (Touitou \& Haus, 1992). Such endogenous rhythms are hardly influenced by changes in external circumstances. Exogenous rhythms, on the other hand, are largely determined by environmental cues and quickly adapt to different situations (Van Acker, 1994).

Eating and drinking tend to occur together and to affect each other; they are clearly episodic behaviours shown predominantly during the diurnal phase of the circadian cycle and are entrained by environmental cues. Drinking and excretory behaviour of pigs as measured in terms of voluntary water intake and urine output over $24 \mathrm{~h}$ has received relatively little scientific attention.

Study of the relationship between feed intake, water consumption and urine quantity/quality during the circadian cycle in pigs is particularly needed as there are several practical consequences of the rhythmicity in relation to water homeostasis, health status and therapy. For instance, $\mathbf{N}$ content in an early morning urine sample might give a value that is too low when compared with a value based on a $24 \mathrm{~h}$ urine collection (Van Acker, 1994). Information on circadian patterns of water intake is interesting not only from the physiological point of view but it may also benefit pig welfare through the planning of water delivery systems and improve the economy of water use, without compromising need, when demand is low. Gill \& Barber (1993) showed that the circadian pattern of water intake by growing pigs given two meals daily $(09.00$ and 16.00$)$ in dry or liquid form is closely associated with feeding time and accounted for 72 and $53 \%$ of $24 \mathrm{~h}$ intake in dry and liquid fed pigs respectively. Intake of water peaked about $1 \mathrm{~h}$ after feeding, with postprandial drinking activity remaining high for about $3 \mathrm{~h}$. A similar circadian pattern of water use by growing pigs fed a dry meal was reported by Bigelow \& Houpt (1988). Barber (1993) monitored the circadian pattern of water consumption via push button drinkers by 14 lactating sows fed twice daily $(07.00$ and 16.00$)$ and found that there were two peaks of drinking during $24 \mathrm{~h}$. The first peak occurred $2 \mathrm{~h}$ after the morning meal (equal to $11.8 \%$ of total daily intake) and the second occurred $3 \mathrm{~h}$ after the evening meal (equal to $9 \cdot 2 \%$ of total daily intake).

Feed associated drinking activity was also observed by Mroz et al. (1995) with nonpregnant sows given free access to water and one meal/d in a dry form (Fig. 1).

Over $24 \mathrm{~h}$ the animals drank 8.31 water and excreted 5.71 urine. Water intake by these sows peaked about $2 \mathrm{~h}$ after feeding with postprandial drinking activity remaining high for 3-4 $\mathrm{h}$ and urine output peaking 9-12 h after the meal. Content of urea in the urine fluctuated substantially $\left(125-400 \mathrm{mmol} \mathrm{l}^{-1}\right)$. Nocturnal drinking activity (from 22.00 to 06.00 ) of the sows was very low and accounted for about $2 \%$ of intake over $24 \mathrm{~h}$. Gill \& Barber (1993) found that in dry and liquid fed pigs the nocturnal drinking activity accounted for about 4 and $12 \%$ respectively.

In summary, circadian patterns of water intake and urine excretion/composition by various categories of pigs as related to feeding regimens have been studied only fragmentarily. Further insight into the underlying mechanisms of spontaneous fluctuations and the regulation of the circadian rhythms is necessary for increasing the accuracy of diagnosing renal and urinary tract disorders and the economy of water use. 


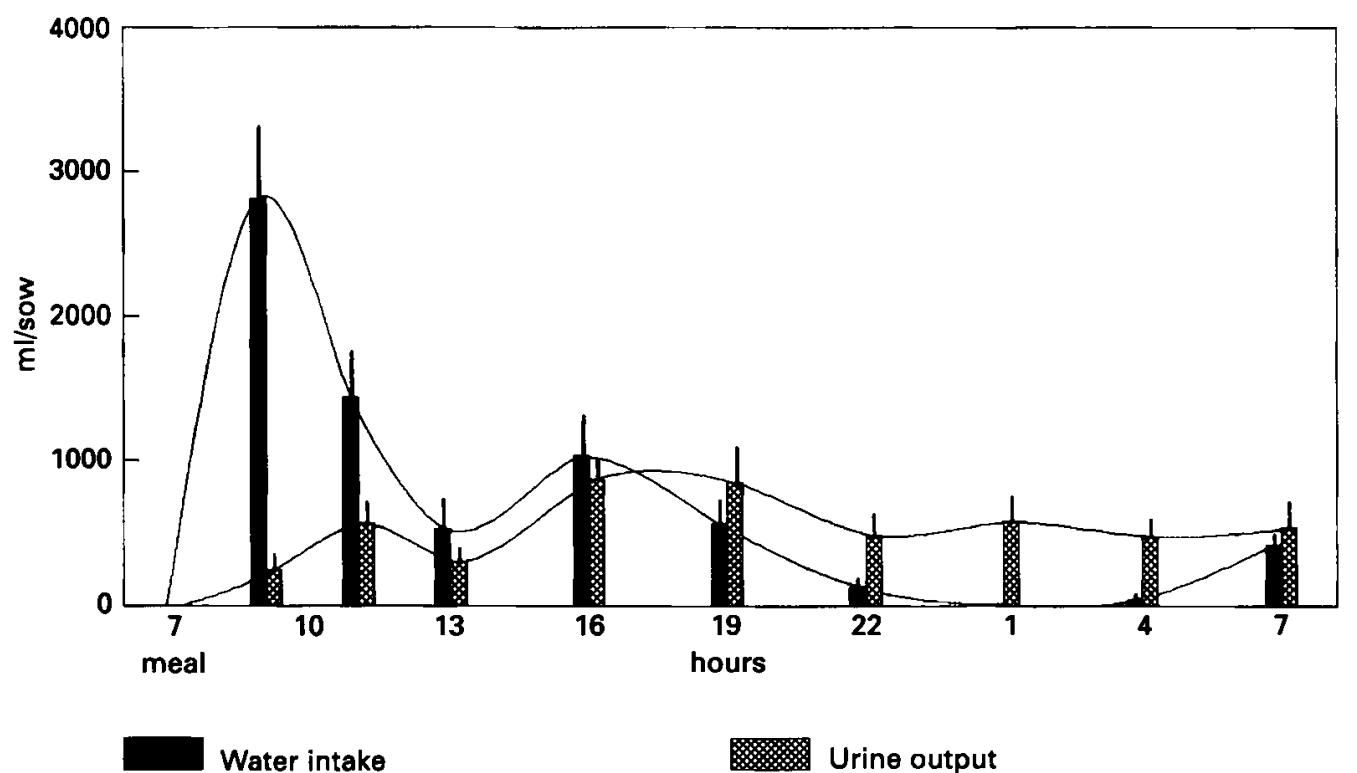

Fig. 1. Circadian patterns of voluntary water intake and urine output by non-pregnant sows fed a dry meal once daily (Mroz et al. 1995).

\section{WATER ALLOWANCES}

Although water is an essential nutrient for pigs, our knowledge of requirements is still far from adequate as water is generally abundant, cheap, and not traded commercially. Besides, establishment of water demand (quality, quantity) is far more complex than for the other nutrients, since the pig needs water not only for its maintenance and growth, but also for a number of physiological functions such as thermoregulation and excretion of excessive minerals, toxins and the end products of catabolism filtered from the blood by the kidneys (Brooks \& Carpenter, 1990; Fraser et al. 1990). It is difficult to assess the minimum daily water requirement for eliminating the end products of catabolism from the blood by the kidney (MacFarlane, 1976) because there is a finite limit, equal to $1 \mathrm{osmol} \mathrm{1}^{-1}$, beyond which the kidneys cannot increase urine concentration. This limit in non-pregnant sows was found in our recent studies to be in the range 1·1-1.4 osmol $1^{-1}$ (Vreman et al. 1994).

Nevertheless, published recommendations (Agricultural Research Council, 1981; National Research Council, 1988; Centraal Veevoederbureau, 1993) serve as a useful basis for discussion. Their limitations, in the context of increasing amounts of waste water from pig production and the conflict between behavioural/welfare needs and the interest in reducing effluent pollution, should stimulate further research on establishing water requirements qualitatively and quantitatively.

Generally, it is known that water allowances for pigs in a thermoneutral environment are related to age, live weight, feed composition/intake and physiological status. From the literature, some indications of water allowances for piglets, growing-finishing pigs and reproductive sows will be briefly discussed. 


\section{PIGLETS}

\section{The sucking piglet}

There is a lack of consensus on provision of water for sucking piglets (Fraser et al. 1990). Some studies reported no water use by piglets younger than 5 days (Wójcik et al. 1978). Nagai et al. (1994) observed that the sucking pig began to drink water $3-5 \mathrm{~h}$ after birth, the amount increasing from $36 \mathrm{ml} \mathrm{d}^{-1}$ at 1 day of age to $403 \mathrm{ml} \mathrm{d}^{-1}$ at 28 days. The average total amount of water consumed by each piglet during 4 weeks was 6.151 in May-June, 7.491 in July-August and 4.62 1 in September. Fraser et al. $(1988,1990)$ reported that the use of drinking water by piglets in the first week after birth varied greatly $\left(0-130 \mathrm{ml} \mathrm{d}^{-1}\right)$, with an average of $46 \mathrm{ml} /$ piglet over the first four days. The authors concluded that piglets drink appreciable amounts of water on the first days after birth especially if their milk intake is limited. Jongbloed et al. (1978) estimated that a sucking piglet up to 4 weeks of age consumes daily about $0.5-1.21$ water from mother's milk plus $0 \cdot 10-0.25$ I drinking water. However, a piglet's water requirements depend greatly on the effective environmental temperature (heat loss due to evaporation increases as ambient temperature increases), birth weight and milk intake (Fraser et al. 1990).

Thirty years ago Aumaitre (1965) published an empirical estimation of water needs of piglets $1-9$ weeks of age, which ranged from 100 to $255 \mathrm{~g} \mathrm{~kg}^{-1}$ body weight (BW) $\mathrm{d}^{-1}$, and the relationship with $\mathrm{BW}$ was:

$$
\text { water intake }=242 \cdot 8 / \mathrm{BW}+78 \cdot 7 .
$$

Nagai et al. (1994) found that water consumption $/ \mathrm{kg} \mathrm{BW}$ remained constant at $51-62 \mathrm{ml}$, regardless of age. Friend \& Cunningham (1966) reported that weekly water consumption by a sucking piglet given creep feed pellets from birth to 7 weeks of age was $84,234,326$, $576,1104,2159$ and $3843 \mathrm{ml}$ respectively. The amount of water consumed in the preweaning period correlates positively with creep feed intake and negatively with sow's milk consumption (Wójcik et al. 1978). Owing to the number of factors involved, water requirements of sucking piglets cannot be stated sufficiently precisely for practical application under various conditions, and free access to water is therefore recommended for the piglet's performance and welfare.

\section{The weaned piglet}

Weaning age, metabolic body size, maintenance conditions and feed quality/quantity are important factors influencing water requirement. In standardized environmental conditions voluntary water consumption is related to heat production $\left(1 \mathrm{~g}\right.$ water $\left.\mathrm{kcal}^{-1}\right)$. The first few days after weaning are stressful and therefore the pattern of water consumption is extremely erratic. The piglet's liquid intake drops dramatically from around $800 \mathrm{ml}$ sow's milk to about $200 \mathrm{ml}$ water as there is a great variation in the time taken for piglets to learn the whereabouts of their new supply of liquid. After about 4 days, water intake increases in a predictable and linear fashion. A weaned piglet normally drinks about 11 water during the 3 days after weaning (Stockill, 1990). This much smaller liquid intake reduces the pig's ability to digest starter diets, resulting in gastrointestinal disorders (diarrhoea) and a check in growth. Encouraging young pigs to drink more may help to prevent dehydration, to stimulate feed intake, and to improve digestibility and overall performance. Barber et al. (1989) indicated that the availability of water influences the amount of water consumed and weaned pigs would not compensate for slow delivery rates in order to increase total intake; as the flow rate increased from $175 \mathrm{ml} \mathrm{min}^{-1}$ to $450 \mathrm{ml} \mathrm{min}$, daily water intake increased from 0.78 to $1.321(P<0.05)$. Also, feed intake and daily gain of the piglets were significantly higher (by 38 and $40 \mathrm{~g} /$ pig respectively). 
Gill (1989) conducted two experiments with weaned piglets 3-6 weeks of age and found a positive correlation between water use $\left(Y, 1 \mathrm{~d}^{-1}\right)$ and feed intake $\left(X, \mathrm{~kg} \mathrm{~d}^{-1}\right)$ :

$$
\begin{aligned}
& \text { Experiment } 1: Y=[0.48+1.13 X]^{2}, \quad\left(r^{2}=0.83, \text { r.s.d. }=0.097\right), \\
& \text { Experiment 2:Y=[0.61+1.06X }]^{2}, \quad\left(r^{2}=0.77, \text { r.s.d. }=0.096\right) .
\end{aligned}
$$

Such a relationship was also reported by Brooks et al. (1984) in studies with 102 weaned piglets between three and seven weeks of age: $Y=0.149+3.053 X\left(r^{2}=0.65\right)$. The authors concluded that the best overall prediction of water consumption (WC) by the piglets was based on feed intake and metabolic BW: WC $\left(\mathrm{d} \mathrm{d}^{-1}\right)=-0.788+2.23 X_{1}+0.367 X_{2} ;\left(r^{2}=\right.$ 0.69 ), where $X_{1}$ is the mean daily dry feed intake in $\mathrm{kg}$ and $X_{2}$ is the metabolic BW $\left(\mathrm{BW}^{0.6}\right)$.

Yang et al. (1981) reported that the pig has a daily limit to total volume of dry solids and water of about $19 \%$ of its body weight. Their results showed that water intake/unit dry matter (DM) intake was minimized when pigs were fed ad lib., whereas when feed intake was restricted, excessive water drinking occurred for physical satisfaction or abdominal fill. This would suggest that a minimum adequate water consumption and ratio to dry matter by growing piglets is achieved with free access to feed. Agricultural Research Council (1981) concluded that a water:feed ratio of $2: 1$ should meet the water requirements of a weaned piglet, but free access to water is recommended in practice. Similar advice for dry feeding systems is given by National Research Council (1988) and Centraal Veevoederbureau (1993).

In conclusion, since the water requirement of weaned piglets is also related to dietary mineral composition (Brooks et al. 1984; Gill, 1989), ambient temperature (Mount et al. 1971; Verstegen, 1987; Fraser et al. 1990) and/or type and delivery rate of drinker (Thulin \& Brumm, 1991; Barber, 1993), there is no precise recommendation for amounts of drinking water which could be applied uniformly for all rearing conditions. Water should therefore be offered ad lib. (Agricultural Research Council, 1981; National Research Council, 1988; Centraal Veevoederbureau, 1993). This recommendation does however conflict with an increasing public concern to reduce slurry production from pigs because of environmental pollution (Greutink, 1993). From the environmental point of view, it is desirable to quantify the impact of particular factors and to be able to establish water supply more precisely for each individual farm in order to maintain the required wellbeing of the animals.

\section{GROWING - FINISHING PIGS}

Many authors have underlined difficulties in stating the exact requirements for water by growing-finishing pigs because of the many variables influencing its consumption (Fraser et al. 1990). The effects of temperature, the kind of diet fed (dry or liquid), the level of feed intake, the quality of feed/water, and/or the size of the pig were reviewed by Gill (1989) and Brooks \& Carpenter (1990). There is agreement that water consumption per unit of dry feed intake decreases with the age or live weight of pigs and increases with the ambient temperature.

Growing-finishing pigs kept within the thermoneutral zone and allowed free access to water drink between 3.9 and $5.01 \mathrm{~kg}^{-1}$ diet (Agricultural Research Council, 1981). By increasing the ambient temperature from 10 to $25^{\circ} \mathrm{C}$, losses of water due to evaporation via the lungs and skin increase from $2 \cdot 2$ to $4 \cdot 21 \mathrm{~d}^{-1}$ (Vandenheede $\&$ Nicks, 1991 ).

Dutch requirements for drinking water (expressed as water:feed ratio) are 2.5:1, 2.25:1 and 2.0:1 for pigs in the live weight ranges $25-40,45-70$ and above $70 \mathrm{~kg}$ respectively (Centraal Veevoederbureau, 1993). De Ruyter (1984) concluded from various experiments carried out at optimal thermal conditions that a minimal water:feed ratio (vol/wt) is $2 \cdot 15: 1,2 \cdot 01: 1$ and $1 \cdot 95: 1$ for pigs weighing $20-50,51-80$ and $81-110 \mathrm{~kg}$ respectively. 
Moreover, Holme \& Robinson (1965) found in one experiment on pigs from 18 to $90 \mathrm{~kg}$ BW that even a restricted water: feed ratio of $1.5: 1$ had no effect on growth rate, feed : gain ratio or carcass quality. This was later partly confirmed by Yang et al. (1981) who concluded from studies on growing pigs of about $30 \mathrm{~kg} \mathrm{BW}$ that when the proportion of water intake to commercially pelleted (CP) feed $\left(180 \mathrm{~g} \mathrm{CP} \mathrm{kg}^{-1} \mathrm{DM}\right)$ is $1 \cdot 5: 1$, the pig can still maintain its water balance. However, Barber (1993) observed that by changing the water:feed ratio from $3 \cdot 25: 1$ to $1.63: 11 \mathrm{~kg}^{-1}$ for sixteen pigs of $34 \mathrm{~kg}$ initial $\mathrm{BW}$, the apparent DM digestibility diminished from 82.9 to $79.1 \%(P<0.05)$, although estimated digestible energy, nitrogen retention and BW were not significantly affected. In line with the latter study, Gill \& Barber (1993) indicated from a performance trial with 32 pigs (offered liquid foods of differing water:meal ratios of $2: 1,2 \cdot 5: 1,3: 1$ and 3.5:1 with separate drinking water available) that the live weight gain increased by $40 \mathrm{~g} \mathrm{~d}^{-1}(P<0.05)$ while the feed conversion ratio decreased by $0.11(P<0.05)$ when the water:meal ratio increased from $2: 1$ to $3 \cdot 5: 1$. In contrast, Castle \& Castle (1956) found no effect of the water:feed ratio from $1 \cdot 5: 1$ to $3 \cdot 75: 1$ on the apparent overall digestibility of dry matter in pigs weighing 30-80 kg. Cai \& Zimmerman (1992) reported that growth rate, feed efficiency and $\alpha$-amino nitrogen in plasma of 12 barrows were not influenced by water-to-feed ratio differences $\left(3: 1\right.$ v. $1 \cdot 5: 11 \mathrm{~kg}^{-1}$ feed).

Barber (1993) reported that the relationship between water intake, metabolic BW and feeding level (two meals/day in dry form) of 160 growing pigs (27-41 kg BW) can be illustrated by the following regression equations:

$$
\begin{array}{lll}
Y=7.85-8.28 X_{1}+3.45 X_{1}{ }^{2}, & r^{2}=0.673, & P<0.001, \\
Y=6.86-0.673 X_{2}+0.0278 X_{2}{ }^{2}, & r^{2}=0.651, & P<0.001,
\end{array}
$$

where $Y=$ mean daily water intake $\left(1 \mathrm{pig}^{-1}\right) ; X_{1}=$ mean daily feed intake $\left(\mathrm{kg} \mathrm{pig}^{-1}\right) ; X_{2}=$ metabolic BW $\left(\mathrm{BW}^{0.75}\right)$. The interrelationship between water demand and feeding levels (restricted $=100 \mathrm{~g}$ feed $/ \mathrm{kg} \mathrm{BW}^{0.75}$ daily $v$. ad lib.) by growing-finishing pigs was estimated by Gill (1989) as follows:

Ad lib.:

$$
\begin{array}{lll}
Y=2 \cdot 5+8 \cdot 18 X_{1}-1.978 X^{2}{ }_{1}, & r^{2}=0.730, & (20-78 \mathrm{~kg} \mathrm{BW}), \\
Y=-1.42+0.25 X_{2}-0.0021 X^{2}, & r^{2}=0.792, & (20-78 \mathrm{~kg} \mathrm{BW}) .
\end{array}
$$

Restricted:

$$
\begin{array}{lll}
Y=1.35+2.57 X_{1} & r^{2}=0.735, & (20-85 \mathrm{~kg} \mathrm{BW}), \\
Y=-1.64+0.27 X_{2}-0.0021 X^{2}, & r^{2}=0.809, & (20-85 \mathrm{~kg} \mathrm{BW}),
\end{array}
$$

where $Y=$ mean daily water intake $\left(1 \mathrm{pig}^{-1}\right) ; X_{1}=$ mean daily feed intake $\left(\mathrm{kg} \mathrm{pig}^{-1}\right) ; X_{2}=$ mean BW $(\mathrm{kg})$. However, in another study of Gill \& Barber (1993) daily water use tended to increase with feeding level from 80 to $110 \mathrm{~g} \mathrm{~kg}^{-1} \mathrm{BW}^{-0.75}$, but the response was not significant. The pigs drank more water per unit of feed intake as the feeding level was reduced, suggesting that water may substitute for feed when daily DM intake decreases. Yang et al. (1984) indicated that when daily DM intake is below $30 \mathrm{~g} \mathrm{~kg}^{-1} \mathrm{BW}$, growing pigs drink to excess (polydipsia), probably because of hunger.

It has become clear from studies of Low (1989) that the larger the meal dry matter size, or the larger the volume of water given with the meal, the faster the initial rate of gastric emptying (Table 5). Despite this evidence, surprisingly, no specific studies have been published until now of the effects of gastric emptying rates, due to the volume of water given, on the ileal digestibility of nitrogen, amino acids or minerals.

Choice of drinker type and system flow rates affect daily water usage as documented by Barber (1993), who found that growing pigs used 0.43-1.031 water less when a bite operated drinker (Arato 80) was installed as compared to a nipple (Monoflo) drinker. 
Table 5. Gastric emptying $\left(\mathrm{g} \mathrm{h}^{-1}\right)$ in pigs of $40 \mathrm{~kg}$ body weight given $850 \mathrm{~g}$ diet and varying levels of water

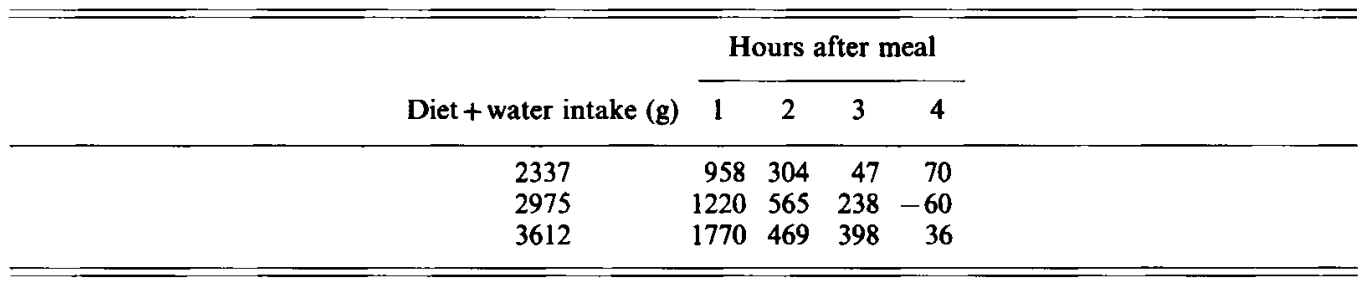

Low, 1989.

In conclusion, according to the Agricultural Research Council (1981), growing-finishing pigs in the range $18-90 \mathrm{~kg} \mathrm{BW}$ tend to drink up to three times as much water as the weight of feed eaten, although there is no strong evidence that restricting water to as little as half this amount has any detrimental effect on overall performance. Brooks \& Carpenter (1990) and Brooks et al. (1989) concluded that the water:feed ratios used in practice cannot ensure adequate performance and therefore, in order to safeguard the welfare of pigs, all pigs should be provided with an unrestricted supply of water. Moreover, the authors remarked that many nutritional studies with fixed, inadequate water supplies are of doubtful validity, since considerable improvements in digestion could be achieved by meeting a real, individual water demand. However, these statements are in contrast with the environmental requirement to minimize manure production. Excessive water supply may result in luxury drinking and losses (spillages) up to 20-30\% (Pollmann et al. 1979; Bauer, 1982), thereby increasing the volume of slurry. In some European countries slurry production is greater than can reasonably be used and therefore contributes to environmental pollution. Since there is evidence that in some circumstances pigs do not voluntarily consume sufficient water to maximize biological performance (Brooks \& Carpenter, 1990), research on water requirements needs to look well beyond the average animal and work is needed on basic principles so that empirical findings can be extrapolated beyond the exact conditions under which they were obtained (Fraser et al. 1990).

\section{REPRODUCTIVE SOWS}

Published estimates of water allowances for sows during various reproductive phases differ markedly. The differences can be ascribed primarily to our poor understanding of the underlying physiological mechanisms regulating water intake, as well as to differences in feed quantity, quality or physical form (dry liquid), systems of management, systems of water delivery, microclimate (ambient temperature, humidity etc.), parity, physiological status (non-pregnant, stage of pregnancy, post-farrowing period, lactation) and health status.

\section{Non-pregnant and pregnant sows}

Relatively few studies have been conducted on water consumption by non-pregnant gilts or sows. Lightfoot \& Armsby (1984) reported that average water intake by non-pregnant sows was 10.01 (range 6.8-13.0 I). In a short test carried out on six individually housed and tethered multiparous non-pregnant sows of $207 \mathrm{~kg} \mathrm{BW}$ allowed free access to drinking water via a bite operated drinker water intake ranged from 5 to $251 \mathrm{~d}^{-1}$, despite using the same daily rations (Mroz et al. 1995). Bauer (1982) also observed that average daily water intake by 15 non-pregnant sows was $11 \cdot 52 \pm 6 \cdot 21$. Such a high individual variation seems to arise partly from stereotyped activity: in response to tethering, some sows develop 
seemingly non-functional repetitive behaviour over several hours in a day resulting in excessive water consumption (Cronin et al. 1986; Fraser et al. 1990). Also, in studies of Friend (1973) with nine unbred gilts over 22 weeks (seven ovulation cycles) it was found that intakes of dry matter and drinking water in the oestrus phase of the first five ovulation cycles were reduced significantly $(P<0.01)$, but not in the last two cycles.

System flow rates affect daily water consumption by sows as demonstrated by Barber (1993) who observed that non-pregnant sows drank daily 8.51 water at a delivery rate of $500 \mathrm{ml} \mathrm{min}^{-1}$ but that this increased to 11.91 when the water delivery rate was $2500 \mathrm{ml} \mathrm{min}^{-1}$.

Dutch estimates of water requirement (Centraal Veevoederbureau, 1993) for reproductive gilts 7 months old (100-105 kg BW) and non-pregnant sows are 6-7 and 8-10 $1 \mathrm{~d}^{-1}$ respectively. In the Agricultural Research Council recommendations (1981) the estimated requirement for non-pregnant sows is $51 \mathrm{~d}^{-1}$. No specific advice is available from the National Research Council (1988), although the possibility of urinary disorders due to water deprivation after weaning is accentuated, as withholding water from the dry sow is a common practice and $60-80 \%$ of sow deaths were caused by kidney and urinary tract disorders (Madec, 1984; Stockill, 1990).

Information on water allowances for pregnant pigs is also scarce. Lightfoot \& Armsby (1984) found that the amount of water consumed by 12 gilts and 12 sows given $1.8 \mathrm{~kg}$ feed d $\mathrm{d}^{-1}$ was 10.01 (range $6 \cdot 8-13 \cdot 1$ ), mainly due to differences in BW. Water consumption in relation to DM intake by 12 pregnant gilts and seven pregnant sows was monitored by Friend (1971). In weeks 1, 3, 5, 7, 9, 11, 13 and 15 the gilts consumed 2.50, $2 \cdot 68,2 \cdot 46,2 \cdot 20,2 \cdot 16,2 \cdot 10,2.07$ and 1.961 water $\mathrm{kg}^{-1} \mathrm{DM}$, while the sows took $3.05,2.46$, $2 \cdot 74,2 \cdot 27,2 \cdot 37,1 \cdot 83,1.92$ and $2 \cdot 241$ water $\mathrm{kg}^{-1} \mathrm{DM}$. Bauer (1982) found in studies on 11 pregnant sows that daily water intake was $14.9( \pm 7.03) 1$. Using 18 crossbred multiparous pregnant sows Pollmann et al. (1979) observed a large variation in water consumption (3.4-46.2 1), and no clear evidence of the effect of stage of pregnancy (days $30 v .80$ ) on water intake was provided. In contrast, Madec et al. (1986) indicated from studies with 59 sows that the average daily water intake up to week 11 of pregnancy was 18.41 , subsequently decreasing to 16.11 . Also, Kuperus (1988) reported an impact of stage of pregnancy since daily intake by 64 sows having free access to water was 28.5 and 20.51 on pregnancy days 40 and 80 respectively. The latter author also indicated that daily water consumption by 24 sows of parity 1, 2, 4 and 7 was 20.5, 29.2, 29.3 and 24.3 respectively. However, Madec et al. (1986) reported no differences in water intake in relation to parity.

Pregnant sows in tether stalls seem prone to excessive drinking. The simple addition of bulk (oat hulls, sida meal) to a concentrated diet increased sow's satiety and reduced daily urine output from 17.3 to 6.3 1 (Mroz et al. 1986; Mroz \& Tarkowski, 1991). Since faecal moisture loss increased minimally, it indicated that the excessive drinking was reduced. A similar effect was reported by Fraser et al. (1990) when straw bedding was provided to tethered sows.

Schellekens (1993) reported from studies under practical conditions in the Netherlands that daily water consumption by non-pregnant and pregnant sows ranged from 6.8 to 7.71 sow $^{-1}$. Requirements for drinking water established by the Centraal Veevoederbureau (1993) are 8-101 until 85 days of pregnancy and then 10-121 until farrowing. The Agricultural Research Council (1981) recommends 5-81 water $\mathrm{d}^{-1}$, irrespective of pregnancy stage. The National Research Council (1988) advises free access to water located near feed dispensers for the welfare of the sow. However, under such conditions confined pregnant sows will probably drink luxury amounts to fill unoccupied active time and the volume of slurry will increase with negative consequences for the environment. A compromise is to withhold water for a specified period daily (Kuperus, 1988; Stockill, 1990) 
but while this offers environmental protection it might compromise animal welfare and health. Interdisciplinary studies are required to solve this dilemma. Fraser et al. (1990) have remarked that, although in many studies the provision of water has been nominally ad lib., the intakes may differ enormously from animal to animal, depending on water quality, the dispensing apparatus, and other aspects of physical and social environment. There may be drawbacks in correlating measured intakes with, for example, aspects of animal health and performance since pigs cannot always be relied upon to consume enough water to maximize biological performance (Brooks et al. 1989).

\section{Lactating sows}

Water consumption of lactating sows is estimated to be at least $40 \%$ higher than that of non-lactating sows, though it is affected by many factors such as stage of lactation (colostral period or advanced lactation; Fraser \& Phillips, 1989), feed intake (Friend, 1971; Bauer, 1982; Gill et al. 1988; Gill, 1989), dietary fibre content (Zoiopoulos et al. 1982), $\mathrm{NaCl}$ intake (Friend \& Wolynetz, 1981), environmental temperature (Bauer, 1982; Kuperus, 1988), type of water dispenser (Diblik, 1986), litter size and hence the piglet's presumed demand for milk (Lightfoot \& Armsby, 1984) and health status (Madec et al. 1986).

Fraser \& Phillips (1989) monitored daily water intake by 40 sows during the 5 days before and 14 days after farrowing. Intake averaged 9-12 $1 \mathrm{~d} \mathrm{~d}^{-1}$ before farrowing, dropped to a mean of 61 on the day of farrowing and increased gradually over 4 days to a plateau of approximately $141 \mathrm{~d}^{-1}$. The authors indicated that some sows are lethargic in the first days after farrowing and fail to consume adequate water, thereby causing low milk production in early lactation and low average weight gains by the piglets.

Mean daily water intake by lactating sows in 12 studies compiled by Fraser et al. (1990) ranged from 8.1 to $25 \cdot 11$ sow $^{-1}$. Similarly, Schellekens (1993) reported from studies in Dutch experimental stations that lactating sows consumed 14-22 I water daily. Gill et al. (1988) found that total daily water consumption via a nose operated drinker during a 3-week lactation averaged 18.91 (range $1-491 \mathrm{~d}^{-1}$ ). Also, Bauer (1982) reported from studies with 44 lactating sows given $4.4 \mathrm{~kg}$ dry feed daily that average water intake was $19.9 \pm 4.21 \mathrm{sow}^{-1}$, and the relationship between water intake $\left(I, 1\right.$ sow $\left.^{-1} \mathrm{~d}^{-1}\right)$ and ambient temperature $\left(T,{ }^{\circ} \mathrm{C}\right)$ was $I=0.92 T-1.52$. Vandenheede \& Nicks (1991) found that evaporative water loss via lungs and skin of a lactating sow weighing $150 \mathrm{~kg} \mathrm{BW}$ at an ambient temperature of $10^{\circ} \mathrm{C}$ was $3.51 \mathrm{~d}^{-1}$ increasing to $7.01 \mathrm{~d}^{-1}$ at $25^{\circ} \mathrm{C}$.

Lightfoot \& Armsby (1984) reported that daily water intake in lactation of 24 sows given $5.0 \mathrm{~kg}$ feed $\mathrm{d}^{-1}$ was 17.71 (range $14.0-21 \cdot 31$ ) presumably due to differences in litter size. Vandenheede \& Nicks (1991) indicated that for lactating sows with five or 10 piglets daily water requirements were 15.8 or 19.81 .

Gill (1989) proposed estimating water intake $(W I)$ by 3-week lactating sows in relation to feed intake in $\mathrm{kg} \mathrm{sow}^{-1}(F)$, sow body weight in $\mathrm{kg}(\mathrm{BW})$, stage of lactation in days postfarrowing $(S)$, litter size suckled $(L)$ and litter weight gain in $\mathrm{kg} / \mathrm{d}(G)$ as follows:

$$
\begin{array}{ll}
W I=4.22+2.52 \mathrm{~F}, & \text { r.s.d. }=4.80 ; r^{2}=0.532, \\
W I=16.1+0.01 \mathrm{BW}, & \text { r.s.d. }=7.12 ; r^{2}=0.01, \\
W I=7.63+1.81 S-0.05 S^{2}, & \text { r.s.d. }=4.91 ; r^{2}=0.515, \\
W I=16.7+0.22 L, & \text { r.s.d. }=7.02 ; r^{2}=0.04, \\
W I=18.1+4.89 G, & \text { r.s.d. }=2.31 ; r^{2}=0.234 .
\end{array}
$$

Not only feed intake, but also high fibre diets affected water intake, as estimated by urine output, which diminished by 7.9 and 11.51 when a conventional diet was fed with addition of oat husks or straw respectively (Zoiopoulos et al. 1982). 
Requirements for drinking water by lactating sows in the Netherlands (Centraal Veevoederbureau, 1993) are related to litter size, sows with 5-7, 8-10 and 11-14 piglets requiring daily 15-20, 20-25 and 25-301 water respectively. The Agricultural Research Council (1981) recommendations are in the range 15-201 d $\mathrm{d}^{-1}$, irrespective of the litter size, although unrestricted access to water supply is advised, as it is by the National Research Council (1988).

Choice of drinker type and system flow rate for lactating sows may affect total water usage. Advisory literature often suggests a flow rate of 21 water $\min ^{-1}$ for lactating sows, but a water flow rate of as little as $0.61 \mathrm{~min}^{-1}$ may be adequate if spillage and management of waste water is not a problem (Fraser et al. 1990). However, Brooks et al. (1989) pointed out that withholding water for long periods of the day is one of the most unacceptable practices in modern pig keeping and, according to Madec (1984), low water intake by sows $\left(<11.51 \mathrm{~d}^{-1}\right)$ appeared to contribute to urinary disorders and especially to severe bacteriuria.

More generally, it seems that the interactions of water intake with nutritional, environmental and husbandry factors may give varying results for reasons that cannot readily be identified. Free access to water over $24 \mathrm{~h}$ favours the animal's wellbeing, defined as the satisfaction of its behavioural and physiological needs, while living in physical and psychological harmony with the environment (Koolhaas et al. 1993). However, free access to water over $24 \mathrm{~h}$ is also questionable since non-physiological, excessive consumption is often observed. Excessive drinking may also have a negative impact on vascular and renal systems (primary polydipsia and/or hyponatraemia when water intake overwhelms renal excretory capacity) as indicated by Rose (1989).

\section{ENVIRONMENTAL IMPLICATIONS}

Intensification of pig production results not only in increased supply of pig meat to consumers, but also in abundant amounts of manure, which contributes increasingly to environmental pollution and eutrophication of drinking water in some countries (Jongbloed, 1987; Barber, 1993). So far, water allowances for pigs have been rarely studied as an integral part of manure production. The quantity and quality of manure excreted is predominantly a reflection of feeding and drinking by pigs, although use of washing water, leaking drinkers and rain water may also affect it (Williams \& Streader, 1990).

Estimated excretion of urine and faeces from particular categories of pigs is presented in Table 6.

The relationship between the amount of water ingested with the feed and the volume of manure from growing-finishing pigs is illustrated by Greutink (1993): at water:feed ratios of $2.5,2.0$ and 1.5 the manure production per year is $1.38,1.01$ and $0.64 \mathrm{~m}^{3}$ per animal respectively. In this calculation it was assumed that $0.11 \mathrm{~m}^{3}$ of water is used for cleaning of pig compartments. The content of DM in manure of pigs fed at water: feed ratios 1.9:1 and $2 \cdot 6: 1$ is estimated to be 13.5 and $7 \cdot 8 \%$ respectively (Centraal Veevoederbureau, 1993). Aarnink \& Van Ouwerkerk (1990) suggested estimating manure production by an individual fattening pig ( $v$ ia faeces and urine) and overall in the pig compartment (including cleaning) from the following equations:

$$
\begin{aligned}
& S_{w, a}=I_{w}-G_{w}-q_{w, a}+M W, \\
& S_{w, h}=I_{w}-G_{w}-q_{w, h}+M W,
\end{aligned}
$$

where: $S_{w, a}=$ amounts of water excreted via faeces and urine by pig $(\mathrm{kg}) ; S_{w, h}=$ amounts of water in total manure (water from faeces + urine + cleaning) during a given fattening period $(\mathrm{kg}) ; I_{w}=$ total water intake $(\mathrm{kg}) ; G_{w}=$ water deposition in the body $(\mathrm{kg}) ; q_{w, a}=$ 
Table 6. Excretion of urine, faeces and water by piglets, growing-finishing pigs and reproductive sows

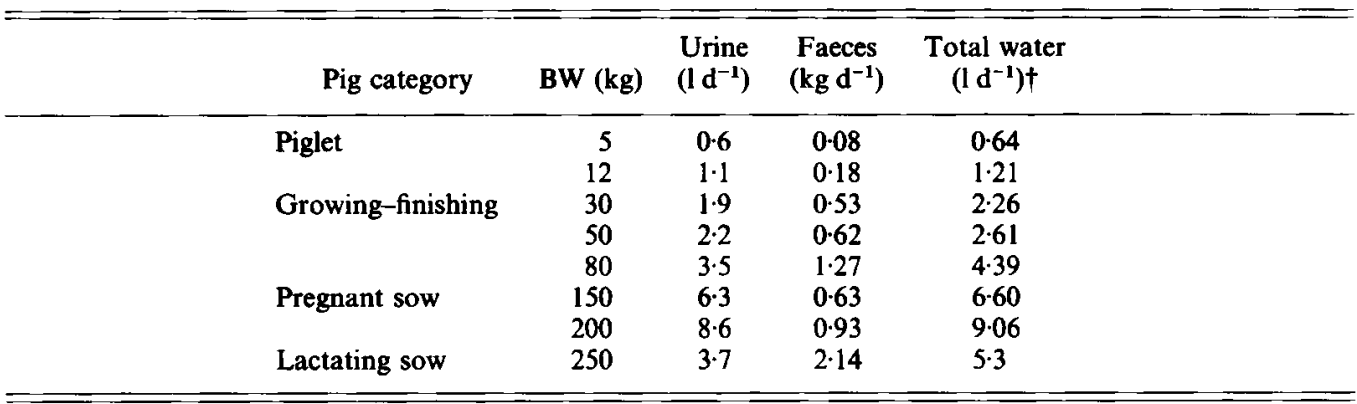

$\dagger$ Assumed $97 \%$ of water in urine and $78 \%$ of water in faeces.

BW, body weight.

Salmon-Legagneur et al. 1973.

water evaporation from an animal $(\mathrm{kg}) ; q_{w, h}=$ water evaporation in the pig compartment $(\mathrm{kg}) ; M W=$ metabolic water $(\mathrm{kg})$.

Williams \& Streader (1990) compared three methods for predicting slurry production based on $(a)$ feed, water and slurry relationships measured in crated and penned pigs; $(b)$ factorial estimates from the literature and $(c)$ measuring the digestibility of feed and of water. The latter method was found to be the best for estimating slurry volume, but underestimated dry matter content in it.

\section{IMPACT OF DIET ON WATER INTAKE AND MANURE PRODUCTION BY PIGS}

There is little available literature on the influence of drinking water supply and other nutrients on amounts and composition of manure from various categories of pigs. This is because the water allowances have rarely been studied as an integral part of nutritional experiments and the environmental implications of this nutrient in pig nutrition were not considered. Among dietary factors known to be particularly inter-related with water intake by pigs are electrolytes and protein.

\section{Dietary electrolytes}

Although it is known that both dietary electrolyte content ( $\mathrm{Na}, \mathrm{K}$ and $\mathrm{Cl}$ ) and cation-anion balance (dEB, dUA) may affect water intake and therefore manure production by pigs, surprisingly little information is available with which to quantify these inter-relationships.

The close association between sodium and chloride in the regulation of water balance has meant that traditionally both electrolytes in the form of supplementary $\mathrm{NaCl}$ have been used in several studies on pigs (Table 7).

It can be calculated from the table below that an increase in dietary $\mathrm{NaCl}$ content of $1 \mathrm{~g} \mathrm{~kg}^{-1}$ resulted in a higher average daily water intake in piglets $(0.52-1.01)$, fattening pigs $(0 \cdot 13-0.431)$, non-pregnant gilts $(0 \cdot 101)$, pregnant gilts $(0.861)$, lactating gilts $(0.401)$ and lactating sows $(0 \cdot 131)$.

Urine output in relation to $\mathrm{NaCl}$ intake was reported by Friend \& Wolynetz (1981), who found in metabolism trials with four gilts before and during pregnancy that when daily $\mathrm{NaCl}$ intake increased from 6.3 to $11.1 \mathrm{~g}$ /gilt, daily water consumption increased from 6.6 
Table 7. The effects of salt intake on water consumption

\begin{tabular}{|c|c|c|c|}
\hline $\begin{array}{l}\text { Pig category } \\
n \text { (live weight) }\end{array}$ & $\begin{array}{l}\mathrm{NaCl} \text { increase } \\
\text { in diet }\left(\mathrm{g} \mathrm{kg}^{-1}\right)\end{array}$ & $\begin{array}{l}\text { Increase in water } \\
\text { intake }\left(\mathrm{d} \mathrm{d}^{-1}\right)\end{array}$ & References \\
\hline \multicolumn{4}{|l|}{ Piglets } \\
\hline $32(17 \mathrm{~kg})$ & $0.6 \rightarrow 2.7$ & $4 \cdot 2 \rightarrow 5 \cdot 3$ & Hagsten \& Perry, 1976 \\
\hline $32(12 \mathrm{~kg})$ & $1 \cdot 1 \rightarrow 2 \cdot 0$ & $3 \cdot 4 \rightarrow 4 \cdot 3$ & Hagsten \& Perry, 1976 \\
\hline \multicolumn{4}{|l|}{ Fattening pigs } \\
\hline $9(49-93 \mathrm{~kg})$ & $0.6 \rightarrow 4.8$ & $6 \cdot 3 \rightarrow 8 \cdot 1$ & Hagsten \& Perry, 1976 \\
\hline $264(23-105 \mathrm{~kg})$ & $1 \cdot 0 \rightarrow 4 \cdot 0$ & $5 \cdot 1 \rightarrow 5 \cdot 5$ & Van Diepen \& Lenis, 1989 \\
\hline & $0 \cdot 0 \rightarrow 5 \cdot 0$ & $4 \cdot 8 \rightarrow 5 \cdot 5$ & Sinclair, 1939 \\
\hline \multicolumn{4}{|l|}{ Non-pregnant gilts } \\
\hline $16(125-202 \mathrm{~kg})$ & $0.0 \rightarrow 5.0$ & $12 \cdot 8 \rightarrow 13 \cdot 3$ & Friend \& Wolynetz, 1981 \\
\hline \multicolumn{4}{|l|}{ Pregnant gilts } \\
\hline $14(133-220 \mathrm{~kg})$ & $0.0 \rightarrow 5.0$ & $10 \cdot 8 \rightarrow 15 \cdot 5$ & Friend \& Wolynetz, 1981 \\
\hline \multicolumn{4}{|l|}{ Lactating gilts } \\
\hline $12(198-162 \mathrm{~kg})^{*}$ & $0.0 \rightarrow 5.0$ & $14 \cdot 2 \rightarrow 16 \cdot 2$ & Friend \& Wolynetz, 1981 \\
\hline \multicolumn{4}{|l|}{ Lactating sows } \\
\hline 16 sows & $1 \cdot 0 \rightarrow 8 \cdot 5$ & $12.9 \rightarrow 13.9$ & Seynaeve \& De Wilde, 1993 \\
\hline
\end{tabular}

* 198 = postfarrow body weight, 162 = end of lactation body weight.

to 8.61 , as well as urine output from 4.9 to 6.11 respectively. However, Seynaeve \& De Wilde (1993) indicated that daily urine output by lactating sows was not related to $\mathrm{NaCl}$ supply $\left(1.0\right.$ v. $\left.8.5 \mathrm{~g} \mathrm{~kg}^{-1}\right)$ and amounted to 3.51 , i.e. c. $27 \%$ of daily water intake.

From studies of Lightfoot \& Armsby (1984) on water consumption and slurry production of dry and lactating sows fed ad lib. it could be concluded that mean slurry output as a proportion of feed and water intake was $0.571(0.42-0.66)$ in pregnancy and $0.421(0.33-0.45)$ in lactation.

Hilliger (1986) reported from a study with 160 fattening pigs $(30-100 \mathrm{~kg} \mathrm{BW})$ that feeding system (liquid meal with water:feed 3:1 v. dry meal, with free access to water via drinkers) had no influence on slurry output $\left(3.9\right.$ v. $\left.3.51 \mathrm{~d}^{-1}\right)$, while water consumption differed (6.6 v. $9.41 \mathrm{~d}^{-1}$ respectively).

Apart from studies with added $\mathrm{NaCl}$, a few studies have been conducted with other sources of $\mathrm{Na}, \mathrm{Cl}$ and $\mathrm{K}\left(\mathrm{NaHCO}_{3}, \mathrm{KHCO}_{3}\right.$ and $\left.\mathrm{KCl}\right)$ in relation to water intake and/or urine output. Patience et al. (1986) reported from a study on four growing pigs of $26 \mathrm{~kg}$ initial BW that supplementation with $\mathrm{NaHCO}_{3}(2.6 \%)$ and $\mathrm{KHCO}_{3}(3.0 \%)$ increased urine volume by 0.63 and $1.031 \mathrm{~d}^{-1}$ respectively $(P<0.025)$.

Results of an experiment of Gill (1989) with growing-finishing pigs of $25 \mathrm{~kg}$ initial body weight fed during 12 weeks either ad lib. or according to weight with one of four levels of dietary potassium, 8, 11,14 and $17 \mathrm{~g} \mathrm{~kg}^{-1}$, are presented in Table 8 . Daily water consumption was clearly related to the dietary $\mathrm{K}$ content, irrespective of the feeding system. Increasing the level of $\mathrm{K}$ by $1 \mathrm{~g} \mathrm{~kg}^{-1}$ increased water intake by $0.111 \mathrm{~d}^{-1}$ when fed according to weight and by $0.061 \mathrm{~d}^{-1}$ when fed ad lib.

According to Brooks \& Carpenter (1990), high electrolyte levels can be tolerated by the pig providing that it has adequate water available to detoxify itself, and the so-called 'salt poisoning' is a misnomer as the condition is not generally a result of a toxic level of salt intake per se but of a disruption of the pig's water balance due to 'water starvation'. However, in the context of reducing environmental pollution it is necessary to provide not an excessive, but a minimal adequate amount of electrolytes for optimal growth and efficiency of feed utilization (Honeyfield \& Froseth, 1985).

Overall, the research has shown that increased intake of salt $(\mathrm{NaCl})$ or individual 
Table 8. Effect of dietary potassium on water demand of ad lib. and scale fed pigs

\begin{tabular}{ccccc}
\hline \multicolumn{1}{c}{ Potassium (g/kg) } & 8 & 11 & 14 & 17 \\
\hline Feeding $100 \mathrm{~g} \mathrm{~kg}^{-1} \mathbf{B W}^{-0.75}$ & & & & \\
$\quad$ Daily feed (kg) & 1.45 & 1.40 & 1.40 & 1.39 \\
$\quad$ Daily water (1) & 4.07 & 4.42 & 4.81 & $5.04^{*}$ \\
$\quad$ Water:feed ratio & 2.81 & 3.16 & 3.44 & 3.62 \\
Ad lib. feeding & & & & \\
$\quad$ Daily feed (kg) & 1.58 & 1.60 & 1.63 & 1.58 \\
Daily water (1) & 4.98 & 5.41 & 5.91 & $5.51^{*}$ \\
Water:feed ratio & 3.15 & 3.38 & 3.62 & 3.49 \\
\hline
\end{tabular}

Brooks et al. 1989; Gill, 1989

* Means within the same row differ significantly $(P<0.05)$.

electrolytes by $1 \mathrm{~g} \mathrm{~kg}^{-1}$ diet results in increased water consumption by $0 \cdot 1-0.41$ and a concomitant increase in urine output. Further quantification of the effects is necessary, particularly with regard to the other acidogenic and/or alkalogenic salts applied in diets for various categories of pigs by feed manufacturers.

\section{Dietary protein}

Few authors have indicated that the quantity and quality of protein in the diet influence water consumption by pigs. According to Thulin \& Brumm (1991) the higher the content of protein in the diet, the greater the water loss, and thus the greater the water requirement. In addition, when a high protein diet is fed there is less metabolic water formed in protein catabolism than is the case with carbohydrates or fats, which also enhances the need for water consumption. The more the amino acid supply deviates from ideal the greater the demand for water: by metabolism of protein equivalent to $100 \mathrm{kcal}$ the net deficit of water is $350 \mathrm{~g}$ (Brooks \& Carpenter, 1990).

In studies of Wahlstrom et al. (1970), 48 crossbred pigs of approximately $27 \mathrm{~kg}$ initial BW were fed up to $91 \mathrm{~kg}$ with a maize-soybean based diet containing either 160 or $120 \mathrm{~g}$ of crude protein (CP) per $\mathrm{kg}$ and two levels of $\mathrm{L}$-lysine $\mathrm{HCl}$ supplied in the drinking water (0 or $1057 \mathrm{mg} \mathrm{l}^{-1}$ ). Average daily water intake was clearly related to the dietary protein concentration, and amounted to 5.3 and $3.91 \mathrm{pig}^{-1}$ when fed 160 and $120 \mathrm{~g} \mathrm{CP} \mathrm{kg}^{-1}$ respectively. Supplementation with lysine had no effect on water consumption.

Close et al. (1983) also measured water intake by 36 entire male pigs of $18-30 \mathrm{~kg}$ initial BW over seven periods, when they were fed on cereal-soybean meal based rations containing 153, 201 and $258 \mathrm{~g} \mathrm{CP} \mathrm{kg}^{-1} \mathrm{DM}$. No clear effect of an increase in CP from 153 to $201 \mathrm{~g} \mathrm{~kg}^{-1} \mathrm{DM}$ on water intake could be seen. However, when CP further increased to $258 \mathrm{~g} \mathrm{~kg}^{-1} \mathrm{DM}$, the pigs drank about $0.04-0.061 \mathrm{~kg}^{-1} \mathrm{BW}$ more than those given 153 or $201 \mathrm{~g} \mathrm{CP} \mathrm{kg}^{-1} \mathrm{DM}$.

Effects of different dietary protein levels on water intake and water excretion by growing pigs were studied by Pfeiffer \& Henkel (1990) and Pfeiffer (1991). In one experiment, eight barrows of $20-100 \mathrm{~kg} \mathrm{BW}$ were fed either barley-soybean meal based diets with 185 or $250 \mathrm{~g} \mathrm{CP} \mathrm{kg}^{-1}$ diet (isoenergetic for metabolizable energy), whereas in a second experiment, eight barrows of $20-30 \mathrm{~kg} \mathrm{BW}$ were fed either a barley-based diet with $125 \mathrm{~g} \mathrm{CP} \mathrm{kg}^{-1}$ or a soybean-starch based diet with $238 \mathrm{~g} \mathrm{CP} \mathrm{kg}^{-1}$. Water and nitrogen balances from both trials are presented in Table 9.

It could be concluded from this table that the pigs showed higher water consumption at higher protein intake. However, on further analysis, the diets differed not only in protein, but also in electrolyte content. Moreover, $\mathrm{N}$ retention in Expt 1 was about $10 \%$ lower when 
Table 9. Water and nitrogen balances for pigs fed various protein levels

\begin{tabular}{|c|c|c|c|c|c|c|}
\hline \multirow[b]{2}{*}{ Protein level } & \multicolumn{3}{|c|}{ Experiment 1} & \multicolumn{3}{|c|}{ Experiment 2} \\
\hline & Low & High & Sign. & Low & High & Sign \\
\hline \multicolumn{7}{|l|}{ Daily intake (g pig ${ }^{-1}$ ) } \\
\hline Dry matter & 1914 & 1910 & - & 870 & 867 & - \\
\hline Crude protein & 319 & 433 & $* *$ & 109 & 206 & $* * *$ \\
\hline Water & 4318 & 5427 & $*$ & 3286 & 4577 & $* *$ \\
\hline \multicolumn{7}{|l|}{ Daily excretion (g pig ${ }^{-1}$ ) } \\
\hline Urine & 1873 & 2893 & $*$ & 1882 & 2999 & ** \\
\hline Faeces & 1186 & 1189 & - & 363 & 209 & $* * *$ \\
\hline \multicolumn{7}{|l|}{ Daily nitrogen balance $\left(\mathrm{g} \mathrm{pig}^{-1}\right)$} \\
\hline $\mathbf{N}$ intake & $49 \cdot 7$ & $76 \cdot 7$ & $* * *$ & $17 \cdot 5$ & $33 \cdot 0$ & $* * *$ \\
\hline$N$ in urine & $13 \cdot 3$ & $32 \cdot 1$ & $* * *$ & - & - & - \\
\hline Urea $\mathbf{N}$ in urine & $10 \cdot 0$ & $26 \cdot 5$ & $* * *$ & - & - & - \\
\hline Ammonia in urine & 0.6 & 0.8 & $* *$ & - & - & - \\
\hline $\mathbf{N}$ in faeces & $12 \cdot 9$ & $16 \cdot 0$ & - & $25 \cdot 6$ & 25.8 & - \\
\hline $\mathbf{N}$ retention (as \% of intake) & $46 \cdot 0$ & $36 \cdot 2$ & - & - & - & - \\
\hline
\end{tabular}

Pfeiffer \& Henkel, 1990. ${ }^{*} P<0.05 ;{ }^{* *} P<0.01 ; * * P<0.001$.

Table 10. Water and nitrogen balance of finishing pigs in relation to protein content in experimental diets

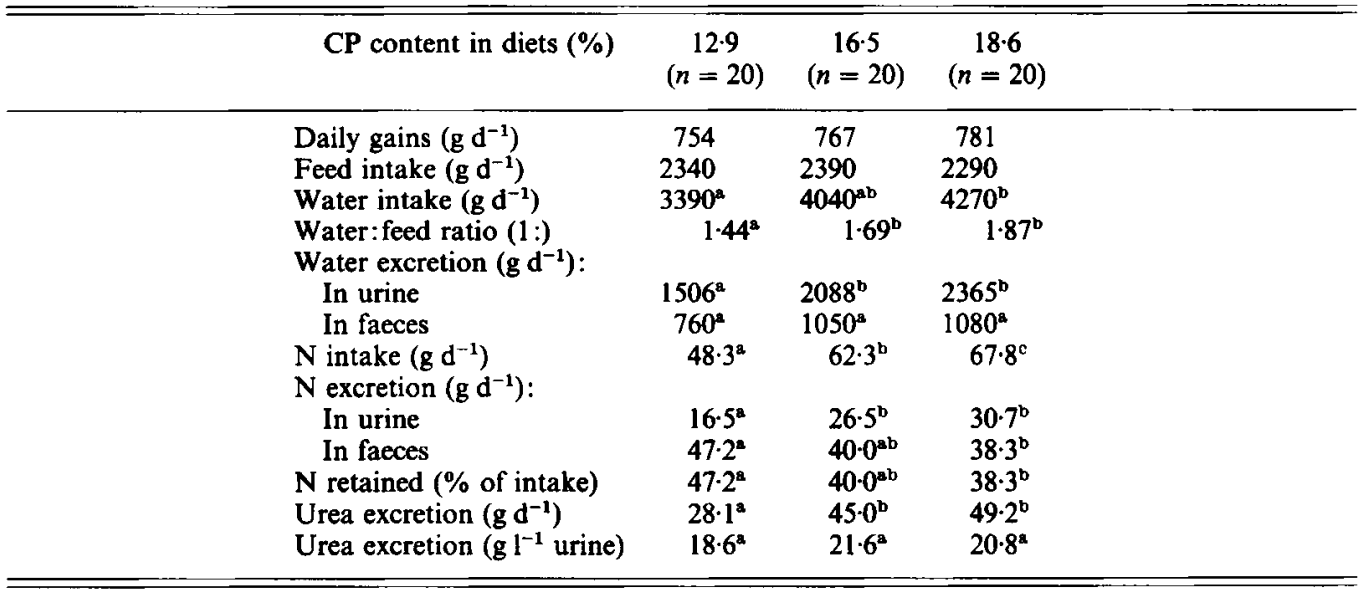

Frémant, 1992

a, b, c Means within a row lacking a common superscript letter differ $(P<0.05)$.

$\mathrm{CP}$, crude protein.

fed the high protein diet, which indicates its poorer biological value. Therefore, it seems that water intake might have been affected by an interactive (confounding) effect of the protein and electrolyte levels. A summary of the extensive studies of Frémaut \& De Schrijver (1991) and Frémaut (1992) on 60 finishing pigs of $70-85 \mathrm{~kg}$ is presented in Table 10.

They formulated three diets based on barley, maize, soybean meal, manioc, wheat, wheat bran, maize gluten meal and fish meal, which contained 129,165 and $186 \mathrm{~g} \mathrm{CP} \mathrm{kg}^{-1}$, with identical energetic value $\left(8.8 \mathrm{MJ} \mathrm{NE}_{\mathrm{f}} \mathrm{kg}^{-1}\right)^{*}$. Water intake, urine production and water

* The term NE, refers to the net energy of fat deposited in the body of pigs. 
content of faeces increased gradually with increasing CP supply. Referring to the above data Fullarton et al. (1992) concluded that the volume of urine can be reduced by $36 \%$ by a reduction in dietary $\mathrm{CP}$ of $56 \mathrm{~g} \mathrm{~kg}^{-1}$. However, this conclusion is not fully justified since, as with the previous studies of Pfeiffer \& Henkel (1990), these effects might have been confounded with differing electrolyte supplies in the compared diets.

In model estimates Aarnink (1991) showed that by feeding growing-finishing pigs a diet containing $100 \mathrm{~g}$ digestible $\mathrm{CP} \mathrm{kg}$, the water requirement is $1.841 \mathrm{~kg}^{-1}$ feed, and by increasing the digestible CP content to $150 \mathrm{~g} \mathrm{~kg}^{-1}$ feed the water requirement is increased to $2.051 \mathrm{~kg}^{-1}$ diet. However, the author provided no indication of which experimental data were used to find this relationship. Besides, estimates from this model are given up to $150 \mathrm{~g} \mathrm{CP} \mathrm{kg}^{-1}$ diet, while in practice much higher levels of digestible protein for young pigs are used.

In spite of confounding effects in most of the available studies, it can be stated that the quantity and quality of dietary protein affect pigs' water consumption and manure production. The lowering of dietary CP concentration in a grower diet by $10 \mathrm{~g} \mathrm{~kg}^{-1}$ decreases water intake and urine volume by $0 \cdot 1-0.31$. This has practical implications for storage costs, reduced spreading requirements (time and fuel) and also reduced odour nuisance as a result of less frequent spreading (Fullarton et al. 1992). However, too little information is available on the impact of various sources of protein, interactions between electrolyte and protein concentrations on water intake, as well as about the influence of amounts and quality of the other nutrients (crude fibre and fat in particular). Moreover, further quantification of water intake in relation to protein supply is particularly needed with regard to reproductive sows, whose manure accounts in the Netherlands for about $44.5 \%$ of the total amounts derived from pig production.

\section{SUMMARY}

Spontaneous drinking of water and its homeostasis in the body are primarily controlled by (a) neurohormonal regulation of the effective circulating volume of blood via various volume receptors and effectors, $(b)$ changes in plasma osmolality regulated mainly by antidiuretic hormone, and $(c)$ changes in cation-anion equilibrium within and between particular body compartments via chemical buffering by the extracellular and intracellular buffers, alterations in alveolar ventilation to control the $p \mathrm{CO}_{2}$, and changes in renal $\mathrm{H}^{+}$ excretion to regulate the plasma $\mathrm{HCO}_{3}{ }^{-}$concentration.

About $75 \%$ of drinking water is taken by pigs in close association with eating, but physiological stimuli for spontaneous drinking are not exactly defined. Hypertonicity and hypovolaemia as drinking stimuli are likely to be overestimated, and gastric secretagogues, as well as increased mucosal blood flow, vascular stretch/distortion and the dryness of the mouth transmitted via chemoreceptors, mechanoreceptors or pressoreceptors to the hypothalamus probably stimulate a pig to drink under normal and stressless conditions.

A rise of about $10 \mathrm{~m} .0 \mathrm{mmol} \mathrm{kg} \mathrm{kg}^{-1}$ in plasma and a fall of $6-7 \%$ in blood volume are indicated in the literature as thresholds for drinking behaviour in growing pigs. Water is absorbed from the intestine through the active (intracellular) and the passive (extracellular) transport pathways. The duodenum and jejunum possess the most permeable epithelia, whereas the stomach is impermeable to water. The active $\mathrm{Na}^{+}$pump at the lateral and basal membranes establishes the electrochemical and osmotic gradients for passive bidirectional water flow into and out of the intestinal lumen.

Quantification of water allowances for particular categories of pigs is still inadequate primarily owing to difficulties in establishing the effect of some extrinsic factors (ambient temperature, humidity, diet quantity and quality, water delivery system, maintenance 
conditions). Thus, the recommended allowances of drinking water for particular categories of pigs under practical conditions are either ad lib. (i.e. with free access over $24 \mathrm{~h}$ or during a selected time of the day) or restricted in amounts (i.e. at a defined ratio to consumed feed). Further studies should aim to investigate each factor, and to establish a minimum adequate intake for specific practical conditions, while also maintaining the animals in a state of optimal wellbeing.

Little information is available on the inter-relationships between dietary electrolytes $(\mathrm{Na}$, $\mathrm{K}, \mathrm{Cl}$ ) and water consumption. Most studies indicate only that increasing dietary $\mathrm{NaCl}$ results in increased water intake and a concomitant increase in urine output. Further studies should aim to define a minimum adequate intake of these electrolytes from various sources at a minimum adequate drinking water supply, to avoid their oversupply and excessive production of urine.

Amounts and origin of dietary protein may affect water consumption and manure production, although quantification of the effects in the available literature is usually imprecise since intentional restrictions in protein supply were usually confounded with an unintentional alteration in electrolyte supply. Further studies are therefore needed on water consumption and manure production as related to various protein sources and levels in diets with equivalent amounts of particular electrolytes.

\section{REFERENCES}

Aarnink, A. J. A. (1991). [Mathematical model for the water requirements of growing pigs.] Instituut voor Mechanisatie, Arbeid en Gebouwen, Rapport no. 8, p. 41.

Aarnink, A. J. A. \& Van Ouwerkerk, E. N. J. (1990). [Computer model for estimating the volume and composition of pig manure.] Instituut voor Mechanisatie, Arbeid en Gebouwen, Rapport no. 229.

Agricultural Research Council (1981). The Nutrient Requirements of Pigs. Farnham Royal: Commonwealth Agricultural Bureaux.

Ahn, D. U., Patience, J. F., Fortin, A. \& McCurdy, A. (1992). The influence of pre-slaughter oral loading of acid or base on post-mortem changes in Longissimus dorsi muscle of pork. Meat Science 32, 65-79.

Anderson, C. R. \& Houpt, T. R. (1990). Hypertonic and hypovolemic stimulation of thirst in pigs. American Journal of Physiology 258, R149-R154.

Argenzio, R. A. (1984). Intestinal transport of electrolytes and water. In Dukes' Physiology of Domestic Animals, pp. 311-326 [M. J. Swenson, editor]. Ithaca, NY: Cornell University Press.

Aumaitre, A. (1965). [Water requirement of piglets.]. Zeitschrift für Tierphysiologie, Tierernährung und Futtermittelkunde 20, 209-217.

Austic, R. E., Boyd, R. D., Klasing, K. C. \& Riley, W. W. (1983). Effect of dietary electrolyte balance on growth performance in swine. Journal of Animal Science 57, 236 (Abstract).

Austic, R. E. \& Patience, J. F. (1988). Undetermined anion in poultry diets: influence on acid-base balance, metabolism and physiological performance. Critical Reviews in Poultry Biology 1, 315-345.

Bailey, M. (1990). The water requirements of poultry. In Recent Advances in Animal Nutrition - 1990, pp. 161-176 [W. Haresign \& D. J. A. Cole, editors]. London: Butterworths.

Barber, J. (1993). The rationalisation of drinking water supplies for pig housing. PhD Thesis, Plymouth Polytechnic \& Seale-Hayne College, Newton Abbot, Devon.

Barber, J., Brooks, P. H. \& Carpenter, J. L. (1989). The effects of water delivery rate on the voluntary food intake, water use and performance of early-weaned pigs from 3 to 6 weeks of age. In The Voluntary Food Intake of Pigs (BSAP Occasional Publication no. 13), pp. 103-104 [J. M. Forbes, M. A. Varley \& T. L. J. Lawrence, editors]. British Society of Animal Production.

Bauer, W. (1982). [Consumption of drinking water by non-pregnant, highly pregnant and lactating gilts.] Archiv für Experimentelle Veterinärmedizin 36, 823-827.

Bigelow, J. A. \& Houpt, T. R. (1988). Feeding and drinking patterns in young pigs. Physiology and Behavior 43, 99-109.

Brooks, P. H. \& Carpenter, J. L. (1990). The water requirement of growing-finishing pigs - theoretical and practical considerations. In Recent Advances in Animal Nutrition - 1990, pp. 115-136 [W. Haresign \& D. J. A. Cole, editors]. London: Butterworths.

Brooks, P. H., Carpenter, J. L., Barber, J. \& Gill, B. P. (1989). Production and welfare problems relating to the supply of water to growing-finishing pigs. Pig Veterinary Journal 23, 51-66.

Brooks, P. H., Russell, S. J. \& Carpenter, J. L. (1984). Water intake of weaned piglets from three to seven weeks old. Veterinary Record 115, 513-515. 
Cai, Y. J. \& Zimmerman, D. R. (1992). Acid-base balance effect on plasma urea N (PUN) and forms of $N$ excretion and water intake effect on PUN in finishing pigs. Journal of Animal Science 69, Suppl. 1, p. 363 (Abstract).

Castle, E. J. \& Castle, M. E. (1956). The rate of passage of food through the alimentary tract of pigs. Journal of Agricultural Science 47, 196-203.

Centraal Veevoederbureau (1993). [Standards.] In Handboek voor de varkenshouderij, pp. 270-300. The Netherlands: Voeding.

Chan, J. C. M. (1974). The influence of dietary intake on endogenous acid production. Theoretical and experimental background. Nutrition and Metabolism 16, 1-9.

Chang, E. B. \& Rao, M. C. (1994). Intestinal water and electrolyte transport. Mechanisms of physiological and adaptive responses. In Physiology of the Gastrointestinal Tract, 3rd edn, pp. 2027-2075 [L. R. Johnson, editor]. New York: Raven Press.

Charney, A. N. \& Feldman, G. M. (1989). Internal exchange of hydrogen ions: gastrointestinal tract. In The Regulation of Acid-Base Balance, pp. 89-105 [D. W. Seldin \& G. Giebisch, editors]. New York: Raven Press.

Chew, R. M. (1965). Water metabolism of mammals. In Physiological Mammalogy, vol. 2, Mammalian Reactions to Stressful Environments, pp. 43-178 [W. V. Mayer \& R. G. Van Gelder, editors]. New York: Academic Press.

Close, W. H., Berschauer, F. \& Heavens, R. P. (1983). The influence of protein:energy value of the ration and level of feed intake on the energy and nitrogen metabolism of the growing pig. 1. Energy metabolism. British Journal of Nutrition 49, 255-269.

Cronin, G. M., van Tartwijk, J. M. F. M., van der Hel, W. \& Verstegen, M. W. A. (1986). The influence of degree of adaptation to tether-housing by sows in relation to behaviour and energy metabolism. Animal Production 42 , $257-268$.

Cumby, T. R., Phillips, V. R. \& Clarkson, C. R. (1993). Farm scale approaches to manure treatment. Misset-Pigs 9, 12-13.

Cunningham, H. \& Friend, D. W. (1966). Effects of water restriction on nitrogen retention and carcass composition of pigs. Journal of Animal Science 25, 663-667.

De Ruyter, A. A. M. (1984). Minimale water/voer verhouding bij mestvarkens. Report CHV. Veghel, The Netherlands.

Desmoulin, B. (1978). [Study of body composition of pigs. Scientific and technical applications.] Journées de la Recherche Porcine en France 7, 211-234.

Diblik, T. (1986). [The effect of type of drinker on the amount of water drunk by sows.] Živočišná Výroba 31, $1029-1036$.

Dubreuil, P., Farmer, Ch., Couture, Y.\& Petitclerc, D. (1993). Hematological and biochemical changes following an acute stress in control and somatostatin-immunized pigs. Canadian Journal of Animal Science 73, 241-252.

Dwyer, J., Foulkes, E., Evans, M. \& Ausman, L. (1985). Acid/alkaline ash diets: time for assessment and change. Journal of the American Dietetic Association 85, 841-845.

Emmett, M. \& Seldin, D. W. (1989). Evaluation of acid-base disorders from plasma composition. In The Regulation of Acid-Base Balance, pp. 213-263 [D. W. Seldin \& G. Giebisch, editors]. New York, Raven Press.

Fraser, D., Patience, J. F., Phillips, P. A,. \& McLeese, J. M. (1990). Water for piglets and lactating sows: quantity, quality and quandaries. In Recent Advances in Animal Nutrition-1990, pp. 137-160 [W. Haresign \& D. J. A. Cole, editors]. London: Butterworths.

Fraser, D. \& Phillips, P. A. (1989). Lethargy and low water intake by sows during early lactation: a cause of low piglet weight gains and survival? Applied Animal Behaviour Science 24, 13-22.

Fraser, D., Phillips, P. A., Thompson, B. K. \& Peeters Weem, W. B. (1988). Use of water by piglets in the first days after birth. Canadian Journal of Animal Science 68, 603-610.

Frémaut, D. (1992). [A study of the requirements for amino acids of Belgian growing pigs ( $20-60 \mathrm{~kg}$ body weight) in relation to production and environment.] $\mathrm{PhD}$ Thesis, Katholieke Universiteit, Leuven, Belgium.

Frémaut, D. \& De Schrijver, R. (1991). [Effect of lowering the crude protein concentration in the diet of pigs on the composition of the manure.] Studiedag der Nederlandstalige Voedingsonderzoekers 16, 71-72.

Friend, D. W. (1971). Self-selection of feeds and water by swine during pregnancy and lactation. Journal of Animal Science 32, 658-666.

Friend, D. W. (1973). Self-selection of feeds and water by unbred gilts. Journal of Animal Science 37, 1137-1141.

Friend, D. W. \& Cunningham, H. M. (1966). The effect of water consumption on the growth, feed intake, and carcass composition of suckling piglets. Canadian Journal of Animal Science 46, 203-209.

Friend, D. W. \& Wolynetz, M. S. (1981). Self-selection of salt by gilts during pregnancy and lactation. Canadian Journal of Animal Science 61, 429-438.

Fullarton, P. J., Cullin, A. W. R. \& Van den Broecke, J. (1992). Dietary manipulation of nitrogen excretion and slurry volume from pigs. In Nitrate and Farming Systems (Aspects of Applied Biology vol. 30), pp. 145-148 [J. R. Archer et al., editors]. Wellesbourne: Association of Applied Biologists.

Gill, B. P. (1989). Water use by pigs managed under various conditions of housing, feeding and nutrition. PhD Thesis, Polytechnic of the South West, Plymouth.

Gill, B. P. \& Barber, J. (1993). Circadian patterns of water use by growing pigs. In Livestock Environment IV. Fourth International Symposium, University of Warwick, pp. 56-63 [E. Collins \& C. Boon, editors]. St Joseph, MI: American Society of Agricultural Engineers. 
Gill, B. P., Brooks, P. H. \& Carpenter, J. L. (1988). Water use by lactating sows. Animal Production 46, 520 (Abstract).

Greutink, T. (1993). [A look at the volume of dung.] INFO-Bulletin Varkenshouderij 2, 14-20.

Gürtler, H., Ketz, H. A., Kolb, E., Schröder, L. \& Seidel, H. (1989). [The physiology of body fluids.] In Lehrbuch der Physiologie der Haustiere, pp. 370-403 [E. Kolb, editor]. Jena: VEB Gustav Fischer Verlag.

Hagsten, I. \& Perry, T. W. (1976). Evaluation of dietary salt levels for swine. I. Effect on gain, water consumption and efficiency of feed conversion. Journal of Animal Science 42, 1187-1190.

Hannon, J. P., Bossone, C. A. \& Wade, C. E. (1990). Normal physiological values for conscious pigs used in biomedical research. Laboratory Animal Science 40, 293-298.

Harper, H. A. (1973). Review of Physiological Chemistry, 14th edn. Los Altos, CA: Lange Medical Publications.

Haydon, K. D. \& West, J. W. (1990). Effect of dietary electrolyte balance on nutrient digestibility determined at the end of the small intestine and over the total digestive tract in growing pigs. Journal of Animal Science 68, $3687-3693$.

Hilliger, H. G. (1986). [Water requirements for drinking and cleaning in animal husbandry.] Deutsche Tierärztliche Wochenschrift 93, 281-344.

Hoffmann, W. E. (1981). A partial list of normal values. In Current Veterinary Therapy. Food, Animal, Practice, pp. 1168-1169. London: J. L. Howard \& W. B. Saunders Company.

Holme, D. W. \& Robinson, K. L. (1965). A study of water allowances for the bacon pig. Animal Production 7, 377-384.

Honeyfield, D. C. \& Froseth, J. A. (1985). Effects of dietary sodium and chloride on growth, efficiency of feed utilization, plasma electrolytes and plasma basic amino acids in young pigs. Journal of Nutrition 115, 1366-1371.

Houpt, T. R. \& Anderson, C. R. (1990). Spontaneous drinking: is it stimulated by hypertonicity or hypovolemia? American Journal of Physiology 258, R143-R148,

Houpt, T. R., Weixler, L. C. \& Troy, D. W. (1986). Water drinking induced by gastric secretagogues in pigs. American Journal of Physiology 251, R157-R164.

Jones, S. D. M., Rompala, R. E. \& Haworth, C. R. (1985). Effect of fasting and water restriction on carcass shrink and pork quality. Canadian Journal of Animal Science 65, 613-618.

Jongbloed, A.W. (1987). Phosphorus in the feeding of pigs. PhD Thesis, University of Wageningen, The Netherlands.

Jongbloed, A. W., Koomans, P., Van der Valk, P. C. \& Rozemond, P. (1978). [Report of the study committee on feed and drinking water supply for pigs.] Instituut voor Veevoedingsonderzoek (IVVO), Lelystad, Rapport no. 126.

Koolhaas, J. M., Baumans, V., Blom, H. J. M., Von Holst, D., Timmermans, P. J. A. \& Wiepkema, P. R. (1993). Behaviour, stress and well-being. In Principles of Laboratory Animal Science, pp. 75-99 [L. F. M. van Zutphen, V. Baumans \& A. C. Beynen, editors]. Amsterdam: Elsevier.

Kornegay, E. T. \& Vander Noot, G. W. (1968). Performance, digestibility of diet constituents and N-retention of swine fed diets with added water. Journal of Animal Science 27, 1307-1312.

Kuperus, W. (1988). [Water intake by pregnant and lactating sows.] Pig Experimental Station Raalte, Report.

Larvor, P. (1983). Minerals: water; potassium, sodium and chloride. In Dynamic Biochemistry of Animal Production (World Animal Science A3), pp. 281-295 [P. M. Riis, editor]. Amsterdam: Elsevier.

Laski, M. E. \& Kurtzman, N. A. (1989). Evaluation of acid-base disorders from the urine. In The Regulation of Acid-Base Balance, pp. 265-283 [D. W. Seldin \& G. Giebisch, editors]. New York: Raven Press.

Lightfoot, A. L. \& Armsby, A. W. (1984). Water consumption and slurry production of dry and lactating sows. Animal Production 38, 541 (Abstract).

Low, A. G. (1989). Research into the digestive physiology of pigs. In Nutrition and Digestive Physiology in Monogastric Farm Animals, pp. 1-15 [E. J. van Weerden \& J. Huisman, editors]. Wageningen: Pudoc.

MacFarlane, W. V. (1976). Water and electrolytes in domestic animals. In Veterinary Physiology, pp. 463-539 [J. W. Phillis, editor]. Bristol: Wright-Scientechnica.

Madec, F. (1984). Urinary disorders in intensive pig herds. Pig News and Information 5, 89-93.

Madec, F., Chariolet, R. \& Dantzer, R. (1986). Relevance of some behavioural criteria concerning the sow (motor activity and water intake) in intensive pig farming and veterinary practice. Annales de Recherches Vétérinaires $17,177-184$.

Madubuike, F. N. (1980). Nutritional interrelationships of minerals and basic amino acids in growing pigs. PhD Thesis, Cornell University, Ithaca, New York, USA.

Miller, E. R., Ku, P. K., Combs, N. R. \& Ullrey, D. E. (1984). Continued studies of the lysine sparing potential of organic salts of potassium in swine diets. Journal of Animal Science 59, 96 (Abstract).

Moughan, P. J. \& Smith, W. C. (1984). The effect of the dietary $\mathrm{Na}^{+}+\mathrm{K}^{+}-\mathrm{Cl}^{-}$balance on the short-term energy and nitrogen metabolism of the growing pig. Journal of the Science of Food and Agriculture 35, 1183-1185.

Mount, L. E., Holmes, C. W., Close, W. H., Morrison, S. R. \& Start, I. B. (1971). A note on the consumption of water by the growing pig at several environmental temperatures and levels of feeding. Animal Production 13, 561-563.

Mroz, Z., Jongbloed, A. W., Van Diepen, J. Th. M., Vreman, K., Kemme, P. A., Jongbloed, R., Lenis, N. P. \& Kogut, J. (1995). Preliminary studies on excretory and physiological consequences of reducing drinking water and dietary protein supply for non-pregnant sows. ID-DLO Report, Institute for Animal Science and Health, Lelystad, The Netherlands. 
Mroz, Z., Partridge, I. G., Mitchell, G. \& Keal, H. D. (1986). The effect of oat hulls, added to the basal ration for pregnant sows, on reproductive performance, apparent digestibility, rate of passage and plasma parameters. Journal of the Science of Food and Agriculture 37, 239-247.

Mroz, Z. \& Tarkowski, A. (1991). The effects of the dietary inclusion of sida meal (Malvaceae) for gilts on the reproductive performance, apparent digestibility, rate of passage and plasma parameters. Livestock Production Science 27, 199-210.

Nagai, M., Hachimura, K. \& Takahashi, K. (1994). Water consumption in suckling pigs. Journal of Veterinary Medical Science 56, 181-183.

National Research Council (1988). Nutrient Requirements of Swine. 9th rev. edn. Washington, DC: National Academy Press.

Parrott, R. F. \& Misson, B. H. (1989). Changes in pig salivary cortisol in response to transport simulation, food and water deprivation, and mixing. British Veterinary Journal 145, 501-505.

Patience, J. F. (1989a). The physiological basis of electrolytes in animal nutrition. In Recent Advances in Animal Nutrition-1989, pp. 211-228 [W. Haresign \& D. J. A. Cole, editors]. London: Butterworths.

Patience, J. F. (1989 b). Water quality and quantity: importance in animal and poultry production. In Proceedings, Allech's Fifth Annual Symposium, pp. 121-138 [T. P. Lyons, editor]. Nicholasville, KY: Alltech Technical Publications.

Patience, J. F., Austic, R. E. \& Boyd, R. D. (1986). The effect of sodium bicarbonate or potassium bicarbonate on acid-base status and protein and energy digestibility in swine. Nutrition Research 6, 263-273.

Patience, J. F., Austic, R. E. \& Boyd, R. D. (1987). Effect of dietary electrolyte balance on growth and acid-base status in swine. Journal of Animal Science 64, 457-466.

Pfeiffer, A. M. (1991). [Effects of reduced protein intake on nitrogen and water balance and feed conversion efficiency in growing pigs.] PhD Thesis, Christian-Albrechts-Universitāt, Kiel, Germany.

Pfeiffer, A. M. \& Henkel, H. (1990). The effect of different dietary protein levels on water intake and water excretion of growing pigs. In Digestive Physiology in Pigs (EAAP Publication no. 54), pp. 126-131 [M. W. A. Verstegen, J. Huisman \& L. A. den Hartog, editors]. Wageningen: Pudoc.

Pollmann, D. S., Danielson, D. M. \& Peo, E. R. (1979). Value of high fiber diets for gravid swine. Journal of Animal Science 48, 1385-1393.

Randall, H. T. (1988). Water, electrolytes, and acid-base balance. In Modern Nutrition in Health and Disease, pp. 108-141 [M. E. Shils \& V. R. Young, editors]. Philadelphia, PA: Lea \& Febiger.

Remer, T. \& Manz, F. (1993). The bioavailability of minerals and organically bound sulfur from foods as an important determinant of renal net acid excretion. In Bioavailability '93: Nutritional, Chemical and Food Processing Implications of Nutrient Availability, pp. 210-214 [U. Schlemmer, editor]. Ettlingen, Germany: Bundesforschungsanstalt für Ernährung.

Rose, B. D. (1989). Clinical Physiology of Acid-Base and Electrolyte Disorders. New York: McGraw-Hill.

Sabatini, S. \& Kurtzman, N. A. (1989). Overall acid-base regulation by the kidney. In The Regulation of Acid-Base Balance, pp. 185-210 [D. W. Seldin \& G. Giebisch, editors]. New York: Raven Press.

Salmon-Legagneur, E., Gayral, J. P., Leveau, J. M. \& Rettagliatti, J. (1973). [Study of several parameters of variation in the composition of piggery effluents.] Journées de la Recherche Porcine en France 10, $285-293$.

Schellekens, J. (1993). [Through rationa] water management: $4 \mathrm{~m}^{3}$ of manure less per sow per year.] INFO-Bulletin Varkenshouderij 3, 12-18.

Schmidt-Nielsen, B., O'Dell, R. \& Osaki, H. (1961). Interdependence of urea and electrolytes in production of a concentrated urine. American Journal of Physiology 200, 1125-1132.

Scott, D. (1971). Renal excretion of acid and base in the pig. Quarterly Journal of Experimental Physiology 56, 169-177.

Scott, D. \& McIntosh, G. H. (1975). Changes in blood composition and in urinary mineral excretion in the pig in response to acute acid-base disturbance. Quarterly Journal of Experimental Physiology 60, 131-140.

Seynaeve, M. \& De Wilde, R. (1993). [Effect of low salt level in the diet on water intake by lactating sows.] Studiedag der Nederlandstalige Voedingsonderzoekers 18, 2.

Sinclair, R. D. (1939). The salt requirement of growing pigs. Scientific Agriculture 20, 109-119.

Spoelstra, S. F. (1978). Microbial aspects of the formation of malodorous compounds in anaerobically stored piggery wastes. PhD Thesis, Agricultural University of Wageningen.

Stockill, P. (1990). Water: why it should not be the neglected nutrient for pigs. Feed International October, $10-18$.

Tamminga, S. \& Verstegen, M. W. A. (1992). Implications of nutrition of animals on environmental pollution. In Recent Advances in Animal Nutrition - 1992, pp. 113-130 [P. C. Garnsworthy, W. Haresign \& D. J. A. Cole, editors]. London: Butterworth-Heinemann.

Thulin, A. J. \& Brumm, M. C. (1991). Water: the forgotten nutrient. In Swine Nutrition, pp. $315-324$ [E. R. Miller, D. E. Ullrey \& A. J. Lewis, editors]. Boston, MA: Butterworth-Heinemann.

Touitou, Y. \& Haus, E. (1992). Biologic Rhythms in Clinical and Laboratory Medicine. Berlin: Springer-Verlag.

Tumbleson, M. E. \& Schmidt, D. A. (1985). Swine clinical chemistry. In Swine in Biomedical Research, pp. 783-807 [M. E. Tumbleson, editor]. New York: Plenum Press.

Vaissaire, J. P. (1982). [Biological and haematological standards.] In Le Porc et Ses Maladies, pp. 149-168 [P. Mornet, J. Tournut \& B. Toma, editors]. Paris: Maloine S.A. Editeur.

Van Acker, B. A. C. (1994). Glomerular filtration rate: accurate measurement and circadian rhythm. PhD Thesis, University of Amsterdam. 
Vandenheede, M. \& Nicks, B. (1991). [Water requirements and drinking water systems for pigs.] Annales de Médecine Vétérinaire 135, 123-128.

Van Diepen, J. Th. M. \& Lenis, N. P. (1989). [Effect of dietary salt levels on water intake and performance of fattening pigs.] Instituut voor Veevoedingsonderzoek (IVVO), Lelystad, Rapport no. 208.

Verstegen, M. W. A. (1987). Cold climate and environment in swine. In Bioclimatology and the Adaptation of Livestock, pp. 68-82 [H. D. Johnson, editor]. Amsterdam: Elsevier.

Vokes, T. (1987). Water homeostasis. Annual Review of Nutrition 7, 383-406.

Vreman, K., Mroz, Z., Jongbloed, A. W., Van Diepen, J. Th. M., Jongbloed, R. \& Lenis, N. P. (1994). Slurry quantity and quality from non-pregnant sows as related to drinking water and dietary protein supplies. In Tagung Schweine- und Geflügelernährung 3, 192-197 [H. Nonn and O. Simon, editors]. Halle/Saale, Germany: Wissenschaftlicher Fachverlag.

Wahlstrom, R. C., Taylor, A. R. \& Seerley, R. W. (1970). Effects of lysine in the drinking water of growing swine. Journal of Animal Science 30, 368-373.

Williams, A. G. \& Streader, W. V. (1990). A comparison of models for predicting slurry production on a pig farm. Biological Wastes 31, 187-197.

Wójcik, S., Wideński, K. \& Mróz, Z. (1978). [Intake of drinking water by piglets fed creep feeds.] Medycyna Weterynaryjna 34, 161-164.

Yang, T. S., Howard, B. \& MacFarlane, W. V. (1981). Effects of food on drinking behaviour of growing pigs. Applied Animal Ethology 7, 259-270.

Yang, T. S., Price, M. A. \& Aherne, F. X. (1984). The effect of level of feeding on water turnover in growing pigs. Applied Animal Behaviour Science 12, $103-109$.

Zoiopoulos, P. E., English, P. R. \& Topps, J. H. (1982). High-fibre diets for ad libitum feeding of sows during lactation. Animal Production 35, 25-33. 